\title{
Gerçekliğin Yeniden İnşası: Arap-İsrail Normalleşmesinin Orta Doğu Basınında Çerçevelenmesi
}

\author{
İsmail Akdoğan ${ }^{*} \&$ Mikail Uğuş** \& Muzaffer Musab Y1lmaz ${ }^{* * *}$
}

\section{Öz}

Bu çalışma, özü itibariyle Arap-İsrail normalleşmesinin Orta Doğu basınında hangi çerçevelerle kamuoyuna sunulduğunu incelemektedir. Çalışmanın temel amacı, bölge basınının bu normalleşme girişimini çerçeveleme biçiminde yer alan benzerlik ve farklılıkları belirlemek ve gözlemlenen çerçeveleme biçimi ile ülkelerin dış politika çizgileri arasında nedensel bir ilişkinin olup olmadığını ortaya çıkarmaktır. Bu amaç doğrultusunda çalışma, "çerçeveleme" yaklaşımını kavramsal zemin olarak almaktadır. Araştırma sürecinde veri toplama tekniği olarak nitel yöntem benimsenmekte, verilerin tahlili ise söylem analizi tekniğiyle yapılmaktadır. Araştırmanın kapsamı, ortak bildirinin imzalandığı 13 Ağustos 2020 ile İbrahim Anlaşması'nın imzalandığı 15 Eylül 2020 tarihleri arasında dört bölgesel güç Türkiye, Suudi Arabistan, İran ve Misır basınında Arap-İsrail normalleşmesine dair haberlerin incelenmesinden ibarettir. Araştırmanın ana argüman1, Arap-İsrail normalleşmesinin Orta Doğu basınında yeniden inşa edilerek farklı çerçevelerle sunulduğu ve bölgesel güçlerin dış politika çizgilerinin haber çerçeveleme biçimini belirlediği yönündedir.

Keywords: İbrahim Anlaşması, Arap-İsrail Normalleşmesi, Haber Çerçeveleme, Medya-Dış Politika İlişkisi, Orta Doğu

Dr., Sakarya Üniversitesi, TR, İletişim Fakültesi, orcid.org/0000-0002-0098-4121, ismailakdogan@sakarya.edu.tr.

** Dr, Öğretim Üyesi, Sakarya Üniversitesi, TR, İletişim Fakültesi, orcid.org/0000-00017250-3369,mikailugus@sakarya.edu.tr.

*** Arş. Gör., Sakarya Üniversitesi, TR, İletişim Fakültesi, orcid.org/0000-0001-9491-1048, muzafferyilmaz@sakarya.edu.tr. 


\title{
Reconstruction of Reality: Framing Arab-Israeli Normalization in Middle Eastern Media
}

\author{
İsmail Akdoğan* \& Mikail Uğuş** \& Muzaffer Musab Yılmaz ${ }^{* * *}$
}

\begin{abstract}
This paper examines the frames in which the Arab - Israeli normalization is presented to the public in the Middle Eastern press. The main purpose of the study is to determine the similarities and differences of the regional powers framing methods of the normalization attempt, and to discover if there is a casual relationship between framing methods and the countries foreign policies. In this direction, the study adopts the "framing" approach as the conceptual basis. For this research, data collection technique and discourse analysis were chosen as qualitative methods in order to analyze the data. The scope of the research consists of news from the media of four regional powers; Turkey, Saudi Arabia, Iran and Egypt from August 13, 2020, the day when the joint declaration was signed, to September 15, 2020, the day when the Abraham Accords were signed. The main argument of the study is that the Arab-Israeli normalization is presented in the Middle Eastern media in a reconstructed way, and the regional powers foreign policy determines the way in which the news are framed.
\end{abstract}

Keywords: Abraham Accords, Arab-Israeli Normalization, Media Framing, Media-Foreign Policy Relation, Middle East

* Dr., Sakarya University, TR, Faculty of Communication, orcid.org/0000-0002-00984121, ismailakdogan@ sakarya.edu.tr.

** Assist. Prof. Dr, , Sakarya University, TR, Faculty of Communication, orcid.org/00000001-7250-3369, mikailugus@sakarya.edu.tr.

*** Res. Assist., Sakarya University, TR, Faculty of Communication, orcid.org/00000001-9491-1048, muzafferyilmaz@sakarya.edu.tr. 


\section{Giriş}

15 Eylül 2020'de ABD Başkanı Donald Trump'ın arabuluculuğuyla İsrail ile iki Arap ülkesi, Birleşik Arap Emirliği (BAE) ve Bahreyn arasında “İbrahim Anlaşması" imzalandı. İmzalanan bu anlaşma, 1948'den bu yana varlığını sürdüren Arap-İsrail ilişkilerinde yeni bir sürecin başladığının belirtilerini taşımaktadır. Anlaşmaya taraf olan Arap ülkeleri, yalnızca İsrail'i bağımsız bir devlet olarak tanımayı ve onunla diplomatik ilişkileri başlatmayı kabul etmediler, aynı zamanda onunla yakın bir bölgesel işbirliği içerisinde olacaklarının taahhüdünü de verdiler. ${ }^{1}$ Böylece daha önce tanımış olan Misır (1979) ve Ürdün (1994) ile birlikte toplam dört Arap ülkesi İsrail'le diplomatik ilişkilerini tesis etmiş oldu. Arap-İsrail anlaşmazlığı, Orta Doğu'nun tarihi en eski ve çözümü en güç meselelerinden biridir. Dolayısıyla bu tarihi anlaşmazlığa ilişkin meydana gelen herhangi bir gelişme hem bölgesel hem de küresel kamuoyunun dikkatini fazlasıyla çekmektedir. Bu sebeple Orta Doğu basını bu anlaşmaya oldukça fazla yer ayırdı. Ancak, söz konusu anlaşmanın Orta Doğu basınında ele alınış tarzı ve sunuluş biçimi konusunda başlıca iki karşıt görüşün hâkim olduğuna tanık olunmaktadır. Basın diline yansıyan baskın görüşlerden biri, Arapİsrail anlaşmazlığının çözümüne yönelik bu anlaşmayı "tarihi adım" şeklinde sunarken, diğer görüş ise Filistin davasına yönelik "tarihi ihanet" olarak sunmaktadır. Bölge basınının haber sunumlarında gözlemlenen bu karşıtlık ile bölgesel güç rekabetinin yol açtığı mevcut kutuplaşma arasında nedensel bir ilişkinin olup olmadığı merak uyandırmaktadır.

$\mathrm{Bu}$ merakı gidermek adına çalışma, Orta Doğu'daki bölgesel güçlerin haber medyasının İbrahim Anlaşması'nı sunum biçimlerini karşılaş̧ırımalı olarak ele almaktadır. Çalışmanın asıl amacı, medya-dış politika ilişkisi hakkındaki mevcut literatürün ileri sürdüğü argümanların geçerliliğini vaka analiziyle sınamaktadır. Bu amaç doğrultusunda, çalışmanın iki temel araştırma sorusu bulunmaktadır. Birincisi, bölgesel güçlerin basını İbrahim Anlaşması'nı hangi çerçevelerle sunmaktadır, çerçeveler arasındaki benzerlikler ve farklılıklar nelerdir? İkincisi, bölgesel güçlerin Orta Doğu'ya yönelik dış politika çizgisi ile bu ülkelerin basınının anlaşmayı

“Abraham Accords Peace Agreement,” The White House, 15 Eylül 2020, https://www. whitehouse.gov/briefings-statements/abraham-accords-peace-agreement-treaty-ofpeace-diplomatic-relations-and-full-normalization-between-the-united-arab-emiratesand-the-state-of-israel/. 
çerçeveleme biçimi arasında nedensel bir ilişki bulunmakta mıdır? $\mathrm{Bu}$ sayede araştırma, medyanın "siyasal iktidarın etkisi altında hareket ettiği", "siyasal iktidar üzerinde etkiye sahip olduğu" ya da "medya ile siyaset arasında karşılıklı bağımlılık bulunduğu" şeklindeki üç ana yaklaşımdan hangisinin geçerli olduğunu gözlemleme imkânına sahip olacaktır.

Çalışma kapsamında, Orta Doğu'da yer alan bölgesel güçler olan Türkiye, İran, Misır ve Suudi Arabistan'ın medya organları incelenmektedir. Bölgesel güç rekabetinin daha ziyade bu ülkeler arasında yaşanıyor olması, araştırmayı bu ülkelerin medyasıyla sınırlı tutma eğilimini ortaya çıardı. İsrail, bölgesel güç statüsüne sahip olmasına rağmen, anlaşmaya doğrudan taraf olması nedeniyle inceleme içine alınmadı. Söz konusu dört bölgesel güç arasında rekabet ve çatışmanın yaşandığı verili alınmakta, böyle bir ilişki biçiminin olup olmaması veya neden yaşandığ 1 araştırmanın kapsamı dışında tutulmaktadır. Öte yandan çalışma, analiz zemini olarak "çerçeveleme" kavramının metin çözümleme yaklaşımını kullanmaktadır. Araştırma sürecinde, nitel araştırma yöntemi benimsenmektedir. Haber kuruluşlarının bu yöntemle taranmasıyla elde edilen nitel veriler, söylem analizi tekniğiyle çözümlenmektedir. Haber kuruluşları ise her bir ülkenin İngilizce yayın yapan gazeteleri arasından -en popüler olan ölçütü esasına göre- üçer tane seçilmesiyle belirlendi.

$\mathrm{Bu}$ kapsamda çalışma, giriş ve sonuç dışarıda tutulduğunda toplam dört ana bölümden meydana gelmektedir. Birinci bölüm, araştırma sürecinde kullanılan kavramsal çerçeveden oluşmaktadır. Burada, öncelikle çerçeveleme kavramı anlatılmakta, ardından da medya-dış politika ilişkisine dair yaklaşımlar ortaya konulmaktadır. İkinci bölümde, araştırma sürecinde kullanılan yöntem üzerinde durulmaktadır. Üçüncü bölüm, elde edilen verilerin tasnifinin yapılması ve tablolar halinde görselleştirilmesinden oluşmaktadır. Son olarak dördüncü bölümde ise tasnif edilen verilerin tahlili yapılmaktadır.

\section{Kavramsal Çerçeve}

\subsection{Haber Çerçeveleme}

1970'lerden itibaren alan yazınında yer almaya başlayan çerçeveleme kavramı, günümüzde siyasal iletişim çalışmalarında sıklıkla başvurulan metin analiz modeli haline gelmiş bulunmaktadır. En genel ifadeyle 
çerçeveleme, medyanın sosyal gerçekliği yeniden inşa ederek kamuoyunu yönlendirme yollarından birini ifade etmektedir. Haber metinlerine uygulanan çerçeveleme tekniği, günlük hayatta meydana gelen olaylar ve konuların bilinçli olarak belirli bir bakış açısıyla kamuoyuna sunulması ve bu suretle kamuoyunun sosyal gerçekliğe ilişkin görüşünün yönlendirilmesi sürecidir. Çerçeveleme kavramını ilk kez sosyoloji alanında kullanan Gregory Bateson, çerçevelemeyi "medyanın sosyal gerçekliğin belirli yönlerini seçme, vurgulama ve sunma eylemi" şeklinde tanımlamaktadır. ${ }^{2}$

Çerçeveleme kavramını medya çalışmaları alanına uyarlayan Gaye Tuchman haber çerçevelerinin sosyal gerçekliği tasnif ve tanımlama süzgecinden geçirerek kamuoyunun meydana gelen gelişmeleri algılama biçimini etkilediğini ifade etmektedir. Haber üretim sürecinde gerçekliğin sosyal olarak inşa edildiği gerçeği üzerinde duran Tuchman, haber üreticilerinin haber metni oluştururken belirli bir bakış açısını yeniden üreterek dolaşıma soktuğuna dikkat çekmektedir. ${ }^{3}$ Benzer bir perspektifi benimseyen Todd Gitlin, medyanın haber metinleriyle ve görsellerdeki ifadelerle ideolojinin açığa çıktığı bir söylem ürettiğini belirtmektedir. Dolayısıyla hâkim siyasi söylemi benimseyen haber çerçeveleri, baskın ideolojiyi yeniden üretmekte ve toplum nezdinde meşrulaştırmaktadır. Ekonomik ve siyasi çıarların belirleyici olduğu haber üretim sürecinin rutin davranışının, gerçekliğin belirli bir yönünün seçilmesi işlemi olduğuna dikkat çeken Gitlin, haber çerçevelemeyi seçme, vurgulama ve dışta bırakma süreci şeklinde tanımlamaktadır. ${ }^{4}$ Benzer şekilde Gamson, çerçeveleri herhangi bir olay ya da konuya anlam veren ve asıl konuyu öne çıkaran "merkezi düzenleyici fikir" olarak tanımlamaktadır. ${ }^{5}$ Van Dijk ise, haber üretim sürecinde başvurulun kaynaklar ve aktarılan alıntıların haber üreten merkezin içinde bulunduğu iktidar ilişkileriyle yakından ilgili olduğunu öne çıkarmaktadır. ${ }^{6}$

Gregory Bateson, Steps to an Ecology of Mind (New York: Ballantine Books, 1972), 277.

Gaye Tuchman, Making News: A Study in Construction of Reality (New York: The Free Press, 1978), 7.

4 Todd Gitlin, The Whole World is Watching (Berkeley: University of California Press, 1980), 11.

5 William A. Gamson, "News as Framing: Comments on Graber," American Behavioral Scientist 33, no. 2 (1989): 157-161.

6 Teun Van Dijk, Racism and The Press (Londra: Routledge, 1991), 174. 
Çerçeveleme kavramını geliştirerek daha sistematik hale getiren Entman, çerçevelerin meydana gelen olaylara dair anlama, açıklama ve anlamlandırma yolu sunduğunu ifade etmektedir. Ayrica Entman'a göre çerçeveleme işlemi, haber metninde vurgulanan anahtar kelimeler, kavramlar, metaforlar, simgeler ve resimler aracıllı̆̆yla belirli bir bakış açısının ön plana çıkarılmasını ifade etmektedir. ${ }^{7}$ Buradan hareketle Entman, çerçeveleme işlemini metne konu olan olayı tanımlama, soruna dair nedensel ilişki kurma, ahlaki değerlendirmede bulunma ve nihai olarak ilgili soruna yönelik çözüm önerisi sunma olmak üzere dört ana aşama üzerine inşa etmektedir. ${ }^{8}$ Haber metninde yer verilen anahtar kelimeler, basmakalıp sözler ve imgeler, söz konusu metnin taşıdığı anlamın kamuoyu tarafindan fark edilmesinde yol gösterici rol üstlenmektedir. ${ }^{9}$ Özetle Entman'a göre çerçeveleme, algılanmış gerçekliğin bazı yönlerini "seçme" ve "ön plana çıkarma", diğer yönlerini "görmezlikten gelme" davranışı olmakla birlikte, bu gerçekliğin belirli bir yönünü "göze çarpma" işlemidir. ${ }^{10}$

Sonuç olarak, yukarıda bahsedilen çalışmalar dikkate alındığında, herhangi bir olay ya da konuya ilişkin haber sunumunun medyanın kamuoyuna basit bir bilgi aktarma ve toplumu haberdar etme işleminden ibaret olmadığı anlaşılmaktadır. Buradan hareketle, siyasal iletişim aracı olarak medya, gerçekliği belirli bir amaç doğrultusunda yeniden inşa ederek okuyucularına sunmaktadır. Çerçeveleme sürecinde, sosyal gerçekliğin bazı unsurları seçilerek ön plana çıkarılırken, aynı gerçekliğin diğer unsurları görmezlikten gelinerek geri plana itilmektedir.

\subsection{Medya ve Dış Politika}

Kitle iletişim aracı olarak medya, siyasal iletişim alanında kilit rol üstlenmekte, siyasal elitlerile sivil toplum arasındakiiletişimi sağlamaktadır. Medyanın kamuoyunu bilgilendirme, yönlendirme ve harekete geçirme işlevleri bulunmaktadır. Bu nedenle siyasal iktidar -hangi siyasal sistemde

Robert M. Entman, "Framing U.S. Coverage of International News," Journal of Communication 41, no. 4 (1991): 6-27.

$8 \quad$ Robert M. Entman, “Framing: Towards Clarification of a Fractured Paradigm," Journal of Communication 43, no. 4 (1993): 51-58.

9 Entman, "Framing," 6-27.

10 Robert M. Entman, Projections of Power, Framing News, Public Opinion and U.S. Foreign Policy (Chicago: Universty of Chicago Press, 2004), 26. 
olursa olsun- medyayı kullanma, denetleme ve kontrol altına alma çabası içerisine girmektedir. Bunun tersine, medyanın siyasi elitleri yönlendirme, onlar üzerinde etki kurma ve onlardan faydalanma gayreti taşıdığ 1 da bir gerçektir. Medyanın toplum üzerinde etki kurma gücü, aynı zamanda ona siyaset üzerinde de etki kurma imkânı tanımaktadır.

Öte yandan, medyanın siyaset kurumuyla ilişkisinin ulusal (iç siyaset) ve uluslararası (dış politika) olmak üzere iki ayrı boyutu bulunmaktadır. $\mathrm{Bu}$ alana dair çalışma yürüten araştırmacılar, medyanın iç politika yapım sürecinde oynadığ rol ile dış politika yapım sürecinde oynadığ rol arasında farklılık olduğunu ifade etmektedirler. Medya üzerindeki siyasi baskının iç politikadan ziyade, dış politika alanında daha fazla hissedildiği ileri sürülmektedir. ${ }^{11}$ Aşağıda görüleceği üzere medyanın dış politika ve uluslararası siyaset alanında etkin bir role sahip olduğu siyasal iletişim, siyaset bilimi ve uluslararası ilişkiler alanına dair çalı̧̧malarda da belirtilmektedir. Soğuk Savaş döneminde (1947-1989) kapitalist blok ile sosyalist blok arasındaki küresel güç mücadelesinde etkili bir aktör olarak ön plana çıkan medya, Soğuk Savaş sonrası dönemde küreselleşme ve iletişim teknolojisinde kaydedilen ilerlemeyle birlikte uluslararası politikadaki bu konumunu daha da güçlendirmiş bulunmaktadır. ${ }^{12}$

Medya-dış politika ilişkisine dair çalışmalar incelendiğinde üç temel yaklaşım öne çıkmaktadır. Bunlardan ilki, "medyanın siyaset kurumu üzerinde etkiye sahipolduğu" yaklaşımıdır. Bubakış açısı, mevcut literatürde CNN etkisi (CNN effect) yaklaşımı şeklinde nitelendirilmektedir. ${ }^{13}$ 20. yüzyılın başında medya-dış politika ilişkisi üzerinde duran Walter Lippmann, dış ilişkiler hakkında kamuoyu algısının oluşmasında medyanın oynadığ kritik role dikkat çekmektedir. ${ }^{14}$ Dış politika yapım sürecinde medyanın etkili bir rol üstlendiğini savunan Bernard Cohen, medyanın dış politika konusunda halkı bilgilendirme işlevinin yanında, karar vericileri eleştirmek ve onların seçimlerini tartışmaya açmak görevinin de olduğunu ileri sürmektedir. ${ }^{15}$ Aynı şekilde "CNN, BM Güvenlik Konseyi’nin 16.

11 Doris Graber, Mass Media and American Politics (Washington: CQ Press, 1989), 336.

12 James Hoge, “Media Pervasiveness," Foreign Affairs 73, no. 4 (1994):136-144.

13 Piers Robinson, The CNN Effect: The Myth of News, Foreign Policy and Intervention (New York: Routledge, 2002), 2.

14 Walter Lippmann, Public Opinion (New York: The Free Press, 1997), 207.

15 Bernard C. Cohen, The Press and Foreign Policy (New Jersey: Princeton University Press, 1965), 5. 
üyesidir" şeklindeki ifadeyi kullanan BM Eski Genel Sekreteri Boutros Ghali (1992-1996), medyanın uluslararası politikada oynadığı role dikkat çekmiştir. ${ }^{16}$ Yine bu paralelde Steven Livingston, politik gündem kurmaya dair bir aktör, arzu edilen politik amaçların elde edilmesine yönelik bir engel ve politik karar alma sürecini hızlandıran bir faktör olmak üzere CNN etkisinin üç belirgin yönüne dikkat çekmektedir. ${ }^{17}$

CNN etkisi kavramı, ilk olarak Vietnam Savaşı (1955-1975) sürecinde "medya-dış politika ilişkisi" üzerine yapılan çalışmalarda kullanılmıştır. $\mathrm{Bu}$ yaklaşım, Vietnam Savaşı sırasında yaşanan gelişmelerin medya vasitasıyla Amerikan kamuoyuna iletilmesinin siyasal elitlerin bu savaşı gerekli gösterme ve sürdürme tavrının sorgulanmasına sebep olduğunu ve bunun sonucunda da ABD'nin Vietnam'dan çekilmek durumunda kaldığını öne sürmektedir. ${ }^{18}$ Mesela David Culbert, yaptığı çalışmada medyanın ABD'nin Vietnam politikasını değiştirmesinde oldukça önemli bir rol oynadığını ortaya koymaktadır. ${ }^{19}$ Medya-siyaset ilişkisinin doğasına yönelik bu bakış açısı özetle, medyanın devletlerin dışa dönük tutum ve davranışlarına ilişkin toplumda kanaatin oluşmasında etkili bir rolü olduğunu, böylece diş politika karar alma sürecini etkilediğini savunmaktadır.

Medya-dış politika ilişsisine dair açıklama getiren ikinci yaklaşım, "medyanın siyaset kurumunun etkisi altında olduğu" yaklaşımıdır. Bu bakış açısı literatürde "rıza üretimi”" (manufacturing consent) ya da diğer bir ifadeyle "propaganda modeli" şeklinde adlandırılmaktadır. Edward Herman ile Noam Chomsky tarafindan literatüre kazandırılan bu yaklaşım, CNN etkisi yaklaşımının tam tersi bir bakış açısını savunmaktadır. $\mathrm{Bu}$ yaklaşımın temel argümanı, medyanın siyasi karar verme sürecini etki altına alan değil, bilakis hükümetlerin içeriye ve dışarıya dönük tutum ve davranışlarını kamuoyu nezdinde meşrulaştıran ve nihayetinde toplumda

16 Philip Seib, Headline Diplomacy: How News Coverage Affects Foreign Policy (Londra: Greenwood Publishing, 1997), 44.

17 Steven Livingston, Clarifying the CNN Effect: An Examination of Media Effect According to Type of Military Intervention (Harvard: Harvard University Press, 1997), 2.

18 Erdem Denk, “Medya ve Uluslararası Politika," Uluslararası İlişkiler 4, no.13 (2007): 147.

19 David Vulbert, “Television's Visual Impact on Decision-Making in the USA,” Journal of Contemporary History 33, no. 2 (1998): 430-437. 
“rıza üretimi”nde bulunan işlevsel bir araç olduğu yönündedir. Diğer bir ifadeyle medya içerikleri, içinde bulundukları toplumun iktidar ilişkileri etrafinda şekillenmekte, para ve güç süzgecinden geçirilen haber metinleri halkın değil, elitlerin çıkarlarını karşılamaktadır. ${ }^{20}$ Buna göre, siyaset yapıcılar (policy-makers), haber yapıcıları (news-makers) uluslararası gelişmeleri belirli bir bakış açısıyla okumaya zorlamaktadır. ${ }^{21}$ Kısaca bu yaklaşım, medyanın hükümetin politikalarını belirlediğini ya da etkilediğini değil, tam aksine hükümet politikalarının etkisi altında hareket ettiğini savunmaktadır.

Medya-siyaset ilişkisinde iç siyaset ve dış politika ayrımının altını çizen David Paletz ve Robert Entman, siyasi elitlerin kendi aralarındaki gücü yeniden dağıtmak amacıyla medyayı kullandıklarına vurgu yapmaktadırlar. ${ }^{22}$ Benzer bir yaklaşımı benimseyen Daniel Hallin, davranış pratiği bakımından "siyasal bağımsızlık ilkesi"nden "siyasi sorumluluk ilkesi"ne doğru bir geçiş yaşayan medyanın, zamanla siyasi otoritenin dil, gündem ve perspektifini benimseme eğilimi sergilediğini ve bu eğilimin dış ilişkiler alanında daha fazla gözlemlendiğini savunmaktadır. ${ }^{23}$ Aynı şekilde Lance Bennet, haber metinlerinin belirli bir konuda siyaset kurumu içerisinde yer alan "hâkim görüş" açısını yansıttı̆̆ını ve kamuoyunun da buna göre oluşturulduğunu ileri sürmektedir. ${ }^{24}$ Siyasetin medya üzerinde hâkimiyet tesis ettiğine ve diş politika haberlerinin sunumunda bu durumun daha belirgin olduğuna dikkat çeken Edward Herman, ana akım medyanın hükümetin hizmetinde olduğunu ve hatta hükümetin politikalarını meşrulaştıran "halkla ilişkiler ordusu" şeklinde hareket ettiğini savunmaktadır. ${ }^{25}$

20 Edward S. Herman ve Noam Chomsky, Manufacturing Consent: The Political Economy of Mass Media (New York: Pantheon Books, 1988), 2.

21 Piers Robinson, "The CNN Effect: Can the News Media Drive Foreign Policy," Review of International Studies 25, no. 2 (1999): 302.

22 David L. Paletz ve Robert M. Entman, Media, Power and Politics (New York: Free Press, 1981), 20.

23 Daniel Hallin, The Unscored War: The Media and Vietnam (New York: Oxford University Press, 1986), 7.

24 Lance Bennet, "Toward a Theory of Press-State Relations in the United States," Journal of Communication 40, no. 2 (1990):106-125.

25 Edward S. Herman, “The Media's Role in U.S. Foreign Policy,” Journal of International Affairs 47, no.1 (1993): 23-45. 
Medya-dış politika ilişkisi hakkındaki üçüncü yaklaşım, "medya ile siyaset kurumu arasında karşılıklı bağımlılık ilişkisinin bulunduğu" şeklindedir. Bu yaklaşım literatürde "siyaset-medya etkileşim modeli" şeklinde adlandırılmaktadır. Bu bakış açısının kurucuları arasında yer alan Nicholas Berry, medya ile dış politika karar verme mekanizması arasındaki ilişkinin karşı1ıklı bağımlılık temelinde gerçekleştiğini ifade etmektedir. ${ }^{26}$ Yine Patrick O'Heffernan, medya ile dış politika yapıcılarını birbirlerini kullanan ve birbirlerinden fayda sağlayan "karşıllklı bağımlı aktörler" olarak tanımlamaktadır. ${ }^{27}$ Siyaset-medya etkileşim yaklaşımına yakın duran Gadi Wolfsfeld, ilk iki yaklaşımın arasında bir yerde konumlanarak, medya ile siyaset kurumunun birbirlerini etkileme durumunun koşullara bağlı olarak değiştiğini dile getirmektedir. ${ }^{28} \mathrm{Bu}$ üçüncü yaklaşımı daha da geliştirerek kavramsal bir boyuta taşıyan Piers Robinson, medyanın duruma göre siyaset kurumunu hem etkileyen hem de ondan etkilenen bir rol oynadığını ileri sürmektedir. Ayrıca medyanın, dış politika hakkında elitler arasında görüş birliği (elite consensus) bulunduğunda "rıza üretimi" doğrultusunda, görüş ayrıllğ 1 (elite dissensus) bulunduğunda ise " $\mathrm{CNN}$ etkisi” doğrultusunda davranış pratiği sergilediğine dikkat çekmektedir. ${ }^{29}$

\section{Araştırma Yöntemi}

Bu çalışma, 15 Eylül 2020'de İsrail, BAE ve Bahreyn arasında imzalanan ve Arap-İsrail ilişkilerinde yeni bir normalleşme süreci başlatan İbrahim Anlaşması'nın Orta Doğu basınında nasıl çerçevelendiğini incelemektedir. Çalışmanın amaç ve kapsamına uygun olarak Türkiye, İran, Suudi Arabistan ve Misır olmak üzere Orta Doğu'da bulunan dört ülkenin internet haber medyası, araştırmanın evrenini oluşturmaktadır. Araştırmanın örneklemi ise, her bir ülkeden uluslararası yayın yapan üçer gazete seçilerek oluşturuldu. İlgili dört ülkenin incelenme konusu olarak belirlenmesinde

26 Nicholas Berry, Foreign Policy and the Press: An Analysis of New York Times' Coverage of U.S. Foreign Policy (New York: Greenwood Press, 1990), xi.

27 Patrivk O'Heffernan, Mass Media and American Foreign Policy (Norwood: Ablex Publishing, 1991), 82.

28 Gadi Wolfsfeld, The Media and Political Conflict (Cambridge: Cambridge University Press, 1997), 56.

29 Piers Robinson, "Theorizing the Influence of Media on World Politics," European Journal of Communication 16, no. 4 (2001): 523-544. 
birden fazla değişken etkili oldu. Bunlardan ilki ve en önemlisi, söz konusu ülkelerin Orta Doğu siyasetine yön veren bölgesel güç statüsüne sahip olan devletler olmalarıdır. Bu dört ülkenin Orta Doğu'da bölgesel güç olarak ön plana çıkması, bölgesel nüfuz mücadelesinin de esas itibariyle bunlar arasında yaşanmasına yol açmaktadır. Bu ülkelerin seçilmesi, özellikle son on yılda şiddetlenen bölgesel güç mücadelesinin medya boyutunun daha net gözlemlenmesi ve medya-dış politika ilişkisine dair daha somut verilere ulaşılması olanağı sağlamaktadır. İkinci olarak, araştırmada karşılaştırmalı tahlil yapılacağından, aynı güç statüsüne sahip olan ülkelerin tercih edilmesinin, elde edilecek bulgular ve ulaş1lacak yargılar hususunda tutarl1lık oluşturacağ 1 düşünülmektedir. Üçüncü olarak, Orta Doğu, farkl1 etnik, dini ve mezhebi çeşitliliğe ev sahipliği yapan bir bölge olduğundan, farklı etnik köken ve mezhep inancına sahip olan ülkeler seçilerek bir yandan örneklemin evreni temsil etme gücü artırılmakta, diğer yandan da kültürel farklılıkların medya üzerinden anlaşmaya yaklaşım üzerindeki etkisini gözlemleme firsatı sunmaktadır.

Gazete örneklemi hususunda, her bir ülkeden uluslararası yayın yapan üç haber kuruluşu seçildi. İngilizce yayın organları, her bir ülkenin bölgeye ve dünyaya açılan kapılarını teşkil etmektedir. Ayrıca, ilgili yayın organlarının seçiminde, ilgili ülkenin uluslararası alanda en fazla takip edilen gazetelerinin seçimi etkili oldu. Türkiye'den Daily Sabah, Hürriyet Daily News ve Yenisafak English, İran'dan Tehran Times, Fars News ve Kayhan International, Suudi Arabistan'dan Al Arabiya, Arab News ve AsSharq al-Awsat ve son olarak Misir'dan Ahram Online, Egypt Independent ve Daily News Egypt olmak üzere dört ülkeden toplam12 gazete incelendi. Verilerin toplanmasına yönelik gazete taraması, İbrahim Anlaşması konusunda imzalan ortak deklarasyon tarihi olan 13 Ağustos 2020 ile nihai anlaşmanın imzalandığı 15 Eylül 2020 arasındaki zaman diliminde yapıldı. Bu süre zarfında 4 ülkenin 12 ayrı haber organında yayımlanan toplam 120 haber incelendi.

Öte yandan araştırma, nitel araştırma yöntemini kullanmaktadır. Nitel veri analizi, sosyal gerçekliğin tanımlanması, anlamlandırılması ve açıklanması sürecinde yardımcı olmaktadır. Böylece, sosyal gerçeklik içerisinde yerleşik olan anlam, araştırma sürecinde elde edilmiş olan verilerin analiz edilmesiyle ortaya çıkarılmaktadır. $\mathrm{Bu}$ amaçla yazılı metinler incelenerek nitel veri toplanmaktadır. Verilerin toplanması işlemi, haber 
kuruluşlarının resmi internet siteleri üzerinden el yordamıyla taranmasıyla yapılmakta, herhangi bir elektronik program kullanılmamaktadır. Verilerin toplanmasında haber kuruluşlarının yalnızca haber metinleri ve köşe yazıları dikkate alınmakta, görsel metinler inceleme dışı tutulmaktadır. Ayrıca, elde edilen nitel verilerin anlamlandırılması sürecinde söylem analizi tekniği kullanılmaktadır. Bu yolla, metin içerisinde söylenenin yanında, söylenmek istenenin ya da ima edilenin tespiti yapılmaktadır. Söylem analizi, incelenen haber metinlerinde başvurulan çerçevelerin tespit edilmesine yardımcı olmaktadır. 


\section{Verilerin Tasnifi}

\section{Tablo I: Tanımlama Yapma}

\begin{tabular}{|c|c|}
\hline Ülkeler & Öne Çıkan Temalar \\
\hline Türkiye & 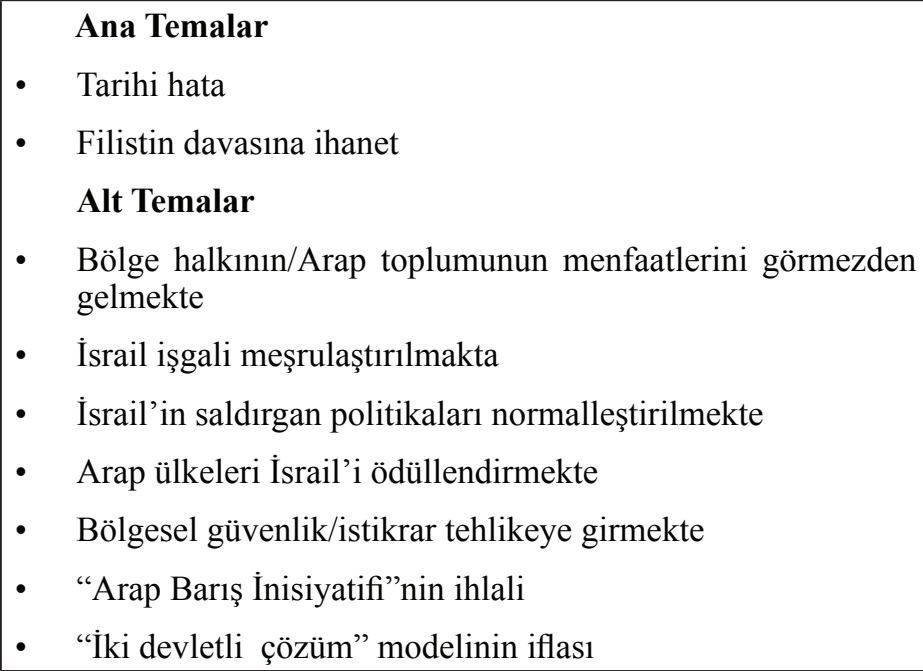 \\
\hline İran & $\begin{array}{ll} & \text { Ana Temalar } \\
\text { - } & \text { Tarihi bir hata } \\
\text { - } & \text { Filistin davasına ihanet } \\
& \text { Alt Temalar } \\
\text { - } & \text { Bölge halkının/Arap toplumunun menfaatlerini görmezden } \\
\text { gelmekte } & \\
\text { - } & \text { İsrail işgali meşrulaştırılmakta } \\
\text { - } & \text { İsrail'in saldırgan politikaları normalleştirilmekte } \\
\text { - } & \text { Arap ülkeleri İsrail'i ödüllendirmekte } \\
\text { - } & \text { Bölgesel güvenlik/istikrar tehlikeye girmekte } \\
\text { - } & \text { Siyonist rejimin menfaatine hizmet } \\
\text { - İşgalci Siyonist rejimle müzakere ve uzlaşma } \\
\text { - }\end{array}$ \\
\hline
\end{tabular}




\begin{tabular}{|c|c|}
\hline $\begin{array}{l}\text { Suudi } \\
\text { Arabistan }\end{array}$ & $\begin{array}{ll} & \text { Ana Temalar } \\
\text { - } & \text { Çözüm umudu } \\
\text { • } & \text { Tarihi adım } \\
\text { - } & \text { Adil, kapsamlı ve kalıcı çözüm } \\
& \text { Alt Temalar } \\
\text { - } \quad \text { İsrail işgali/ilhakının önüne geçmekte } \\
\text { - } \quad \text { Bölgesel güvenlik/istikrar sağlanmakta } \\
\text { - } \quad \text { Filistin davasıyla çelişmemekte } \\
\text { Bölgesel kalkınma/sosyal refah artmakta }\end{array}$ \\
\hline Misir & $\begin{array}{ll} & \text { Ana Temalar } \\
\text { - } & \text { Çözüm umudu } \\
\text { • } & \text { Tarihi adım } \\
\text { - } & \text { Adil, kapsamlı ve kalıcı çözüm } \\
& \text { Alt Temalar } \\
\text { - } & \text { İsrail işgali/ilhakının önüne geçmekte } \\
\text { - } & \text { Bölgesel güvenlik/istikrar sağlanmakta } \\
\text { - } & \text { Filistin davasıyla çelişmemekte } \\
\text { - } & \text { Bölgesel kalkınma/sosyal refah artmakta }\end{array}$ \\
\hline
\end{tabular}




\section{Tablo II: Sebep-Sonuç İlişkisi Kurma}

\begin{tabular}{|c|c|}
\hline Ülkeler & Öne Çıkan Temalar \\
\hline Türkiye & $\begin{array}{ll} & \text { Ana Temalar } \\
\text { • } & \text { Rejim güvenliği } \\
\text { • } & \text { Silah tedariki } \\
& \text { Alt Temalar } \\
\text { • } & \text { Yayılmacı politikaların meşrulaştırılması } \\
\text { - } & \text { Bölgesel nüfuzun önüne geçme }\end{array}$ \\
\hline İran & $\begin{array}{ll} & \text { Ana Temalar } \\
\cdot & \text { Rejim güvenliği } \\
\cdot & \text { Silah Tedariki } \\
& \text { Alt Temalar } \\
\text { • } & \text { Yayılmacı politikaların meşrulaştırılması } \\
\text { - } & \text { Bölgesel nüfuzun önüne geçme }\end{array}$ \\
\hline $\begin{array}{l}\text { Suudi } \\
\text { Arabistan }\end{array}$ & $\begin{array}{ll} & \text { Ana Temalar } \\
\text { • } & \text { Arap Stratejik Aklı } \\
\text { • } & \text { Diplomatik/Barışçıl Çözüm } \\
& \text { Alt Temalar } \\
\text { • } & \text { Bölgesel barış } \\
\text { - } & \text { Bölgesel refah } \\
\end{array}$ \\
\hline Misır & $\begin{array}{ll} & \text { Ana Temalar } \\
\text { • } & \text { Arap Stratejik Aklı } \\
\text { • } & \text { Diplomatik/Barış̧̧ıl Çözüm } \\
\text { • } & \text { Alt Temalar } \\
\text { • } & \text { Bölgesel barış/güvenlik } \\
\text { - } & \text { Bölgesel refah }\end{array}$ \\
\hline
\end{tabular}


Tablo III: Ahlaki Değerlendirmede Bulunma

\begin{tabular}{|c|c|}
\hline Ülkeler & Öne Çıkan Temalar \\
\hline Türkiye & $\begin{array}{ll} & \text { Ana Temalar } \\
\text { - } & \text { Mağduriyet } \\
\text { - } & \text { Insanlık dramı } \\
& \text { Alt Temalar } \\
\text { - } & \text { Seçim propagandası } \\
\text { - } & \text { İç siyasete alet etme } \\
\text { - } & \text { Zorlama, baskı ve tehdit } \\
\text { - } & \text { Güç tahkimi } \\
\end{array}$ \\
\hline İran & $\begin{array}{ll} & \text { Ana Temalar } \\
\text { - } & \text { Mağduriyet } \\
\text { - } & \text { Insanlık dramı } \\
& \text { Alt Temalar } \\
\text { - } & \text { Seçim propagandası } \\
\text { - } & \text { İç siyasete alet etme } \\
\text { - } & \text { Güç tahkimi } \\
\text { - } & \text { Zorlama, baskı ve tehdit }\end{array}$ \\
\hline $\begin{array}{l}\text { Suudi } \\
\text { Arabistan }\end{array}$ & $\begin{array}{ll} & \text { Ana Temalar } \\
\text { - } & \text { Mağduriyetinin giderilmesi } \\
\text { - } & \text { Kültürel farklılıklara saygı gösterilmesi } \\
\text { - } & \text { Egemen devlet vurgusu } \\
\text { - } & \text { İçişlerine karışmama } \\
& \text { Alt Temalar } \\
\text { - } & \text { Siyasi tutarsızlık } \\
\text { - } & \text { Siyasi tutarlılık } \\
\end{array}$ \\
\hline Misır & $\begin{array}{ll} & \text { Ana Temalar } \\
\text { - } & \text { Filistin halkının mağduriyetinin giderilmesi } \\
\text { - } & \text { Kültürel farklılıklara saygı gösterilmesi } \\
\text { - } & \text { Egemen devlet vurgusu } \\
\text { - } & \text { İçişlerine karışmama } \\
\text { - } & \text { Alt Temalar } \\
\text { - } & \text { Siyasi tutarsızlık } \\
\text { - } & \text { Siyasi tutarlılık }\end{array}$ \\
\hline
\end{tabular}




\section{Tablo IV: Çözüm Önerisi Sunma}

\begin{tabular}{|c|c|}
\hline Ülkeler & Öne Çıkan Öneriler \\
\hline Türkiye & $\begin{array}{ll} & \text { Ana Öneriler } \\
\text { • } & \text { Anlaşmadan geri adım atılmalı } \\
\text { • } & \text { Tüm İslam devletlerinin görüşleri alınmalı } \\
& \text { Alt Öneriler } \\
\text { • } & \text { İsrail'in saldırgan davranışları meşrulaştırmamalı } \\
\text { • } & \text { Arap/İslam ülkeleri ortak hareket etmeli } \\
\text { - } & \text { ABD’nin dayatmalarına karşı çıkıllmalı } \\
\text { • } & \text { İran, Türkiye ve Katar bölgede birlikte hareket etmeli } \\
\text { - } & \text { Hamas ile el-Fetih liderlerinin görüşleri dikkat alınmalı } \\
\text { • } & \text { İsrail, işgal ettiği topraklardan çekilmeden ve Filistin devletini } \\
& \text { tanımadan anlaşma imzalanmamalı } \\
\text { • } & \text { İki devletli cözüm önerisine geri dönülmeli }\end{array}$ \\
\hline İran & $\begin{array}{ll} & \text { Ana Öneriler } \\
\text { • } & \text { Anlaşmadan geri adım atılmalı } \\
\text { • } & \text { Tüm İslam devletlerinin görüşleri alınmalı } \\
& \text { Alt Öneriler } \\
\text { • } & \text { İsrail'in saldırgan davranışları meşrulaştırmamalı } \\
\text { - } & \text { Arap/İslam ülkeleri ortak hareket etmeli } \\
\text { • } & \text { ABD’nin dayatmalarına karşı çıkılmalı } \\
\text { - } & \text { İran, Türkiye ve Katar bölgede birlikte hareket etmeli } \\
\text { - } & \text { Hamas ile el-Fetih liderlerinin görüșleri dikkate alınmalı }\end{array}$ \\
\hline
\end{tabular}




\begin{tabular}{|c|c|}
\hline & 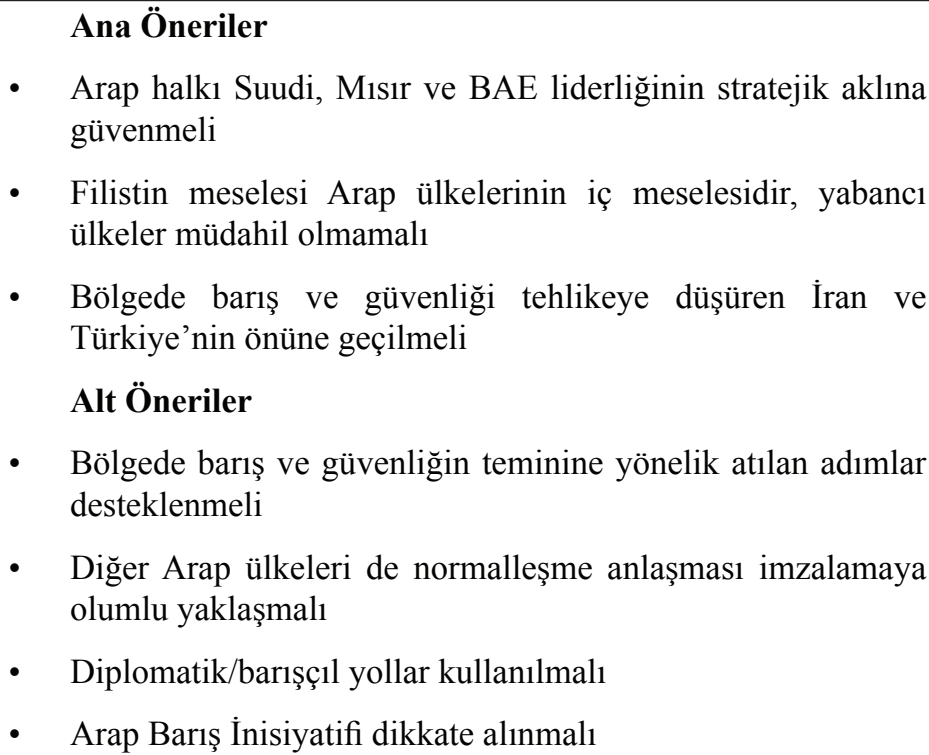 \\
\hline Misır & 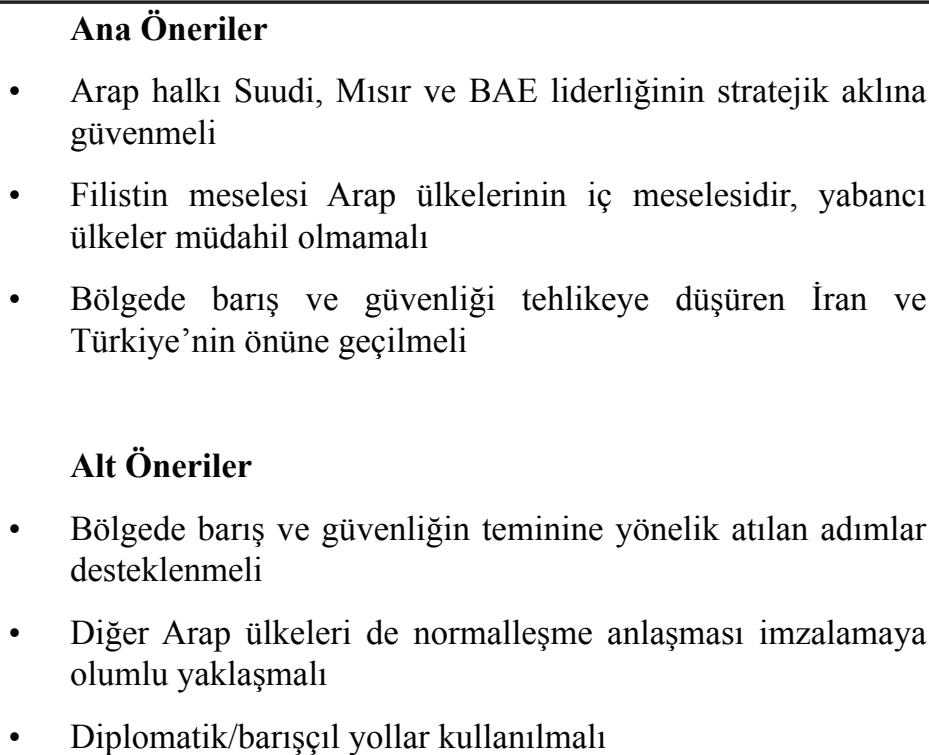 \\
\hline
\end{tabular}




\section{Verilerin Tahlili}

Araştırma sürecinde elde edilen veriler kavramsal çerçeve bölümünde yer verilen model esas alınarak bir önceki bölümde tasnif edilmiştir. $\mathrm{Bu}$ bölümde ise, tasnif edilen veriler tahlil edilmektedir. Toplanan verilere dair tahlil işlemi, iki aşamada yürütülmektedir. İlk aşama, incelenen ülkelerin yazılı medyasının Arap-İsrail normalleşmesi kapsamında imzalanan İbrahim Anlaşması'nı uluslararası kamuoyuna sunarken nasıl çerçevelediği üzerinde durmaktadır. İkinci aşama ise, medyanın söz konusu gelişmeyi çerçeveleme biçimi ile ilgili ülkelerin Orta Doğu'ya yönelik diş politika çizgileri arasında nedensel bir ilişkinin olup olmadığını incelemektedir. Dolayısıyla ilk aşamada çalışmanın birinci araştırma sorusuna, ikinci aşamada ise diğer araştırma sorusuna yanıt aranmaktadır.

\section{1. İbrahim Anlaşması'nın Çerçevelenmesi}

Bu doğrultuda ilk önce sorunun nasıl tanımlandığına ilişkin kategori (Tablo I) ele alınmaktadır. Genel olarak dört ülke medyasının ilgili gelişmeyi nasıl tanımladığına bakıldığında, her ne kadar aralarında küçük farklılıklar olsa da, Türkiye ile İran medyas1, Mısır ile de Suudi Arabistan medyası arasında büyük benzerlikler bulunmaktadır. İmzalanan anlaşmayı ve beraberinde gelen gelişmeleri Türkiye ve İran medyası olumsuz tanımlarken, buna karşılık Mısır ve Suudi Arabistan medyası olumlu olarak tanımlamaktadır. Böylece tek bir sosyal gerçeklik bu dört ülke medyasında farklı şekillerde tanımlanmakta ve iki karşıt bakış açısı ön plana çıkarılmaktadır. Genel olarak değerlendirildiğinde Türkiye ve İran medyası, Arap ülkelerinin İsrail'le ilişkilerini normalleştirme girişimini "tarihi bir hata" ve "Filistin/ İslam davasına ihanet" şeklinde tanımlamaktadır. ${ }^{30}$ Yayın organlarının benimsediği bu iki ana tema, öncelikle İsrail'le normalleşmeye giden ve

30 "UAE made strategic mistake by normalizing ties with Israel, says advisor," Tehran Times, 24 Ağustos 2020, https://www.tehrantimes.com/news/451642/UAE-madestrategic-mistake-by-normalizing-ties-with-Israel-says; "Iranian Speaker's Aide: UAE to Be Engulfed in Zionist Regime's Fire,” Fars News Agency, 14 Ağustos 2020, https://www.farsnews.ir/en/news/13990524000505/Iranian-Speaker39-s-Aide-UAEBe-Englfed-in-Zinis-Regime39-s-Fire; "Wake up call for Palestinian cause," Daily Sabah, 7 Eylül 2020, https://www.dailysabah.com/politics/news-analysis/wake-upcall-for-palestinian-cause; "UAE, Israel deal not surprising, but shameful," Yenisafak English, 15 Ağustos 2020, https://www.yenisafak.com/en/news/uae-israel-deal-notsurprising-but-shameful-3536897. 
buna olumlu yaklaşan Arap ülkelerinin hem kendi halklarının ve hem de Filistin halkının ve yönetiminin taleplerini görmezden geldiğine dikkat çekilerek desteklenmektedir. ${ }^{31}$

Bununla birlikte bu iki ana tema, İsrail'in bölgedeki saldırgan tutum ve davranışlarına dikkat çeken alt temalarla daha da güçlendirilmektedir. Arap ülkelerinin İsrail'i tanımakla onun bölgede yürüttüğü "işgal ve ilhakı meşrulaştırdığı" ve bölgede takip ettiği "saldırgan politikalarını normalleştirdiği" öne çıkarılmaktadır. ${ }^{32}$ Dolayısıyla haber metinleri, tutum ve davranışları nedeniyle Arap ülkelerinin İsrail'e bedel ödetmek yerine, onu ödüllendirdiğine dikkat çekmektedir. Bu yeni sürecin "bölgesel güvenlik ve istikrarın tehlike içerisine girmesiyle sonuçlanacağı" vurgulanmaktadır. ${ }^{33}$ İki ülke medyası bahse konu normalleşmeyi tanımlamaya ilişkin büyük bir benzeşme gösterse de normalleşmeyi tanımlama sürecinde başvurulan alt temalarda ayrışma da söz konusudur. İran medyasından farklı olarak, Türkiye medyasında "Arap barış inisiyatifinin ihlali" ve "iki devletli çözümün iflası” şeklinde iki farklı alt tema kendini göstermektedir. ${ }^{34}$ Öte yandan Türkiye medyasından farklı olarak, İran medyası "işgalci Siyonist rejimle müzakere edildiği” ve "direniş ekseninin hedef alındığı" şeklindeki alt temalara yer vermektedir.

31 "Rouhani Urges Betrayers of Palestine Not to Claim Arabism," Fars News Agency, 16 Eylül 2020, https://www.farsnews.ir/en/news/13990626000994/Rhani-UrgesBerayers-f-Palesine-N-Claim-Arabism; "Israel-UAE deal null and void for Turkey," Yenişafak English, 15 Ağustos 2020, https:/www.yenisafak.com/en/news/israel-uaedeal-null-and-void-for-turkey-3536894.

32 "Iran Urges Muslim Parliaments to Act Against UAE-Israel Deal," Kayhan, 18 Ağustos 2020, http://kayhan.ir/en/news/81905/iran-urges-muslim-parliaments-to-act-againstuaeisrael-deal; "Deal with the devil," Kayhan, 14 Ağustos, 2020, http://kayhan.ir/en/ news/81744/deal-with-the-devil; "The UAE-Israel agreement and the Arab World," Daily Sabah, 26 Ağustos 2020, https://www.dailysabah.com/opinion/columns/theuae-israel-agreement-and-the-arab-world.

33 "UAE-Israel agreement will threaten the national security of the region: Qatari analyst," Tehran Times, 23 Ağustos 2020, https://www.tehrantimes.com/news/451587/UAEIsrael-agreement-will-threaten-the-national-security-of-the. "UAE-Israel intelligence base on Yemeni island of Socotra," Daily Sabah, 5 Eylül 2020, https://www.dailysabah. com/opinion/op-ed/uae-israel-intelligence-base-on-yemeni-islandof-socotra.

34 "Turkey mulls withdrawing envoy, suspending ties with Abu Dhabi over deal with Israel," Hurriyet Daily News, 14 Ağustos 2020, https://www.hurriyetdailynews. com/turkey-mulls-withdrawing-envoy-suspending-ties-with-abu-dhabi-over-dealwith-israel-157389; "Arab League slammed for not condemning UAE-Israel deal," Yenisafak English, 10 Eylül 2020, https://www.yenisafak.com/en/news/arab-leagueslammed-for-not-condemning-uae-israel-deal-3548940. 
Diğer taraftan, benzer çerçeveleri kullanan Misır ve Suudi Arabistan medyasının sorunu tanımlama biçimine bakıldığında, Arap-İsrail normalleşmesi ve yakınlaşmasının olumlu bir gelişme olarak tanımlanarak okuyucularına sunulduğu görülmektedir. Haber medyasında "tarihi adım", “çözüm umudu" ve "adil/kalıcı/kapsamlı bir çözüm” şeklindeki üç ana tema ön plana çıkarılmaktadır. ${ }^{35}$ Okuyucuya aktarılan bu üç ana tema, alt temalarla güçlendirilmektedir. Bu kapsamda, Arap ülkelerinin İsrail'le ilişkilerini normalleştirme yönünde attıkları adımların Filistin Davası ile çelişmediği, tam tersine onunla örtüştüğü ve İsrail işgalinin/ ilhakının önüne geçilmeye çalışıldığı belirtilmektedir. ${ }^{36}$ Üstelik "bölgesel kalkınmanın sağlanacağı" ve "halkın sosyal refahının artacağı" şeklindeki alt temalarla okuyucuya sunulmaktadır. ${ }^{37}$ Meydana gelen gelişmenin, çatışma, anlaşmazlık ve kargaşanın hâkim olduğu Orta Doğu'da "güvenlik ve istikrarın sağlanmasına katkı sağlayacağı" şeklindeki ifadeye yer verilerek, ${ }^{38}$ benimsenen olumlu yaklaşım kamuoyu nezdinde meşrulaştırılmaya çalışılmaktadır.

35 "UAE, Israel reach 'historic deal' to normalize relations," Arab News, 16 Ağustos 2020, https://www.arabnews.com/node/1718936/middle-east; "Oman Supports UAE Decision to Normalize Ties with Israel," As Sharq Al Awsat, 14 Ağustos 2020, https:// english.aawsat.com/home/article/2447746/oman-supports-uae-decision-normalizeties-israel; "Bahrain-Israel peace treaty welcomed regionally, internationally," Daily News Egypt, 12 Eylül 2020, https://dailynewsegypt.com/2020/09/12/bahrain-israelpeace-treaty-welcomed-regionally-internationally.

36 "UAE, Israel reach 'historic deal' to normalize relations," Arab News, 16 Ağustos 2020, https://www.arabnews.com/node/1718936/middle-east. "Bahrain-Israel peace treaty welcomed regionally, internationally," Daily News Egypt, 12 Eylül 2020, https:// dailynewsegypt.com/2020/09/12/bahrain-israel-peace-treaty-welcomed-regionallyinternationally/

37 "UAE 'willneverabandon'Palestinians, Senior Official Says after Israel Deal," AlArabiya, 17 Eylül 2020, https://english.alarabiya.net/en/News/middle-east/2020/09/17/UAEwill-never-abandon-Palestinians-senior-official-says-after-Israel-deal;"UAE position on Palestine in line with Arab consensus, says diplomat," Arab News, 15 Ağustos, 2020, https://www.arabnews.com/node/1719976/middle-east;"Pompeo to tour region after UAE-Israel deal," Ahram Online, 23 Ağustos 2020, http://english.ahram.org. eg/NewsContent/2/8/378381/World/Region/Pompeo-to-tour-region-after-UAEIsraeldeal.aspx. "UAE, Israel strike deal to normalize ties, halt annexation plans," Daily News Egypt, 13 Ağustos 2020, https://dailynewsegypt.com/2020/08/13/uae-israelstrike-deal-to-normalize-ties-halt-annexation-plans.

38 "UAE, Israel reach 'historic deal' to normalize relations," Arab News, 13 Ağustos 2020, https://www.arabnews.com/node/1718936/middle-east. "In Israel, Kushner says 'stage is set' for Mideast progression," Egypt Independent, 30 Ağustos 2020, https:// egyptindependent.com/in-israel-kushner-says-stage-is-set-for-mideast-progress/. 
İkinci olarak, meydana gelen gelişmeye ilişkin sebep-sonuç ilişkisi kurma kategorisi (Tablo II) tahlil edildiğinde, incelenen dört ülke medyasında benzerlik ve farklılıklar burada da gözlemlenmektedir. Olayı olumsuz tanımlayan Türkiye ve İran medyasının benzer temalar üzerinden sebepsonuç ilişkisi kurduklarına tanık olunmuştur. ABD, İsrail ve Arap ülkelerinin bölge politikaları ve birbirleriyle olan ilişkileri üzerinden sebep-sonuç ilişkisi kurulmaktadır. Türkiye ve İran medyasında "rejim güvenliği”" ile "silah tedariki" olmak üzere iki ana tema öne çıkarılmaktadır. ${ }^{39}$ Burada "halktan kopuk" ve "siyasi meşruiyeti zayıf" bazı Arap yönetimlerinin ABD ve İsrail'le yakınlaşma içerisine girerek kendi rejimlerini güvence altına almaya çalıştıklarına işaret edilmektedir. ${ }^{40}$ Bunun yanında, askeri güç kapasitelerini artırmak isteyen Arap ülkelerinin ABD'den ileri teknolojiye sahip silah tedarikinde bulunabilmek için ABD'nin yönlendirme ve baskılarına boğun eğmek durumunda kaldıkları ileri sürülmektedir. Bununla ilgili olarak İsrail'le normalleşme görüşmeleri yapıldığı esnada, BAE'nin ABD'den 23,3 milyar dolar tutarında 50 adet F-35 tarzı savaş uçağ1 alımına dair görüşmelere yer verilmektedir. ${ }^{41}$

Ayrıca, sebep-sonuç ilişkisi “bölgesel nüfuzun önüne geçme" ile "yayılmacı davranışları meşrulaştırma" olmak üzere iki alt temayla güçlendirilmektedir. Arap ülkeleri, İsrail ve ABD’nin Türkiye ile İran'1n artan “bölgesel nüfuzunu

39 "UAE and S. Arabia are part of the Zionist project in West Asia: Saudi analyst," Tehran Times, 16 Ağustos 2020, https://www.tehrantimes.com/news/451283/ UAE-and-S-Arabia-are-part-of-the-Zionist-project-in-West-Asia; "Saudi Arabia's Zionist Connection," Kayhan, 8 Eylül 2020. http://kayhan.ir/en/news/82594/saudiarabia $\%$ E2\%80\%99s-zionist-connection; "UAE-Israel intelligence base on Yemeni island of Socotra," Daily Sabah, 5 Eylül 2020, https://www.dailysabah.com/opinion/oped/uae-israel-intelligence-base-on-yemeni-islandof-socotra; "Trump Ready to Sell Any Weapons to 'Wealthy'Arabs," Kayhan, 15 Eylül 2020, http://kayhan.ir/en/news/82856/ trump-ready-to-sell-any-weapons-to- $\% \mathrm{E} 2 \% 80 \% 98$ wealthy\%E2\%80\%99-arabs.

40 "UAE-Israel agreement will threaten the national security of the region: Qatari analyst," Tehran Times, 23 Ağustos 2020, https://www.tehrantimes.com/news/451587/ UAE-Israel-agreement-will-threaten-the-national-security-of-the; "UAE, Israel deal against democracy in Arab world: Experts," Yenisafak English, 15 Ağustos 2020, https://www.yenisafak.com/en/news/uae-israel-deal-against-democracy-in-arabworld-experts-3536895.

41 "Netanyahu Privately Accepts Arms Sales to UAE," Kayhan, 4 Eylül 2020, http:// kayhan.ir/en/news/82433/netanyahu-privately-accepts-arms-sales-to-uae; "Trump says UAE interested in buying F-35 jets, willing to pay 'a lot of money'," Yenisafak English, 20 Ağustos 2020, https://www.yenisafak.com/en/news/trump-says-uaeinterested-in-buying-f-35-jets-willing-to-pay-a-lot-of-money-3537234. 
kırmayı" arzulamalarının, bahse konu yakınlaşmaya zemin hazırladığı ileri sürülmektedir. Benzer şekilde, bölgedeki "saldırgan ve yayılmacı davranışlarına meşruiyet kazandırmak" isteyen İsrail ve ABD'nin Arap ülkeleriyle böyle bir yakınlaşmayı önemsediklerine dikkat çekilmektedir. ${ }^{42}$ Buna karşılık Mısır ve Suudi Arabistan medyasında "Arap stratejik aklı" ve "diplomatik çözüm" gibi iki ana tema dikkatleri üzerine çekmektedir. Arap ülkelerinin İsrail'le ilişkilerini normalleştirme yöneliminin, "Arap stratejik aklını" kullanmalarının ve Arap-İsrail anlaşmazlığının çözümüne dair "diplomatik/barışçıl yolu" benimsemelerinin bir sonucu olduğu aktarılmaktadır. ${ }^{43}$ Bununla birlikte, bölge halklarının "güvenlik, barış ve refah" gibi temel önceliklerinin karşılanması hedefi olarak değerlendirilmektedir. ${ }^{44}$

Üçüncü olarak, haber metinlerindeki ahlaki değerlendirme temalarına (Tablo III) bakıldığında benzer bir tabloyla karşılaşılmaktadır. Türkiye ve İran medyası "insanlık dramı" ve "halkın mağduriyeti" ana temalarını öne çıkarmaktadır. Arap ülkelerinin İsrail'le yakınlaşması durumunda Filistin topraklarında yaşanan insanlık dramının daha derinleşeceği, Filistin halkının yeni bir mağduriyete uğratılacağı işlenmektedir. ${ }^{45}$

42 "Historic agreements boost Trump's image as a peacemaker," Arab News, 15 Eylül 2020, https://www.arabnews.com/node/1735051; "Zarif's assistant says UAE-Israel agreement not beneficial to the region," Tehran Times, 18 Ağustos 2020, https://www. tehrantimes.com/news/451422/Zarif-s-assistant-says-UAE-Israel-agreement-notbeneficial-to.

43 "UAE position on Palestine in line with Arab consensus, says diplomat," Arab News, 15 Ağustos 2020, https://www.arabnews.com/node/1719976/middle-east; "Mauritania affirms support for UAE following Israel deal to normalize relations," Al Arabiya, 16 Ağustos 2020, https://english.alarabiya.net/en/News/gulf/2020/08/16/Mauritaniaaffirms-support-for-UAE-following-Israel-deal-to-normalize-relations; "Peace deal at the White House," Ahram Online, 15 Eylül 2020, http://english.ahram.org.eg/ NewsContent/50/1203/381169/AlAhram-Weekly/World/Peace-deal-at-the-WhiteHouse.aspx.

44 "Halting annexation top UAE priority in Israel 'historic' deal: UAE official," $A l$ Arabiya, 17 Ağustos 2020, https://english.alarabiya.net/en/News/gulf/2020/08/17/ Halting-annexation-top-UAE-priority-in-Israel-historic-deal-UAE-official; "UAE, Israel reach 'historic deal' to normalize relations," Arab News, 16 Ağustos 2020, https:// www.arabnews.com/node/1718936/middle-east; "First Israel-Emirates commercial flight set for Monday," Ahram Online, 28 Ağustos 2020, http://english.ahram.org.eg/ NewsContent/2/8/378801/World/Region/First-IsraelEmirates-commercial-flight-setfor-Mon.aspx.

45 "Iran Urges Muslim Parliaments to Act Against UAE-Israel Deal," Kayhan, 18 Ağustos 2020, http://kayhan.ir/en/news/81905/iran-urges-muslim-parliaments-to-act-against- 
Ahlaki değerlendirme alt temalarla sürdürülmektedir. ABD ve Arap ülkelerinin Arap-İsrail anlaşmazlığını iç siyasetlerine alet ettiklerine dikkat çekilmektedir. İsrail ile Arap ülkelerini müzakere masasına oturtan Donald Trump'ın Kasım 2020'de gerçekleştirilen başkanlık seçimlerinde İsrail yanlısı seçmen nezdinde gücünü konsolide etmeye çalıştı̆̆ üzerinde sıklıkla durulmaktadır. ${ }^{46}$ Diğer taraftan incelenen basın organlarında, Veliaht Muhammed bin Selman ve Veliaht Muhammed bin Zayid gibi Suudi Arabistan ve BAE'nin filli yöneticileri haline gelen iki genç hanedan üyesinin iç politikada güçlerini tahkim edebilmek amacıyla ABD'nin desteğine ihtiyaç duyuyor olmalarına dikkat çekilmektedir. ${ }^{47}$ Dolayısıyla Arap liderlerinin, Trump yönetimin zorlaması/baskısı nedeniyle İsrail'le normalleşmeye olumlu yaklaşmak durumunda kaldıkları öne çıkarılmaktadır. ${ }^{48}$ Aynı zamanda Arap ülkelerinin İsrail'in şantaj ve tehditlerine boyun eğmek zorunda kaldıklarına değinilmekte, İsrail' in "anlaşma imzalanmazsa işgal devam eder" şeklindeki ifadesine

uaeisrael-deal; “Arab parties, groups decry Bahrain-Israel pact," Yenisafak English, 12 Eylül 2020, https://www.yenisafak.com/en/news/arab-parties-groups-decry-bahrainisrael-pact-3549080; "Hamas urges world leaders to break silence on Israel's Gaza blockade," Daily Sabah, 24 Ağustos 2020, https://www.dailysabah.com/world/mideast/hamas-urges-world-leaders-to-break-silence-on-israels-gaza-blockade.

46 "Rouhani warns UAE: Lest deal with Tel Aviv open a way for Israeli presence in the region," Tehran Times 15 Ağustos 2020, https://www.tehrantimes.com/news/451275/ Rouhani-warns-UAE-Lest-deal-with-Tel-Aviv-open-a-way-for-Israeli; "Trump wants Jewish votes, UAE wants US arms, Israel wants Palestinian lands," Daily Sabah, 17 Ağustos 2020, https://www.dailysabah.com/opinion/columns/trump-wants-jewishvotes-uae-wants-us-arms-israel-wants-palestinian-lands; "Trump-Netanyahu 'peace Show,"” Daily Sabah, 22 Eylül 2020, https://www.dailysabah.com/opinion/oped/trump-netanyahu-peace-show; "UAE-Israel deal breaks Arab unity, endangers Palestinian cause, experts say," Daily Sabah, 11 Eylül 2020, https://www.dailysabah. $\mathrm{com} /$ politics/news-analysis/uae-israel-deal-breaks-arab-unity-endangers-palestiniancause-experts-say.

47 "UAE and S. Arabia are part of the Zionist project in West Asia: Saudi analyst," Tehran Times, 16 Ağustos 2020, https://www.tehrantimes.com/news/451283/UAEand-S-Arabia-are-part-of-the-Zionist-project-in-West-Asia; "How much is Palestine worth?," Daily Sabah, 18 Eylül 2020, https:/www.dailysabah.com/opinion/columns/ how-much-is-palestine-worth.

48 "Deals of Shame," Fars News Agency, 17 Eylül 2020, https://www.farsnews.ir/ en/news/13990627000810/Deals-f-Shame; "Did MBS give assurance to US of normalization with Israel?," Daily Sabah, 11 Eylül 2020, https://www.dailysabah. com/opinion/columns/did-mbs-give-assurance-to-us-of-normalization-with-israel; "Arab nations, stop the man who is dragging you to war against Turkey!,", Yenisafak English, 11 Eylül 2020, https://www.yenisafak.com/en/columns/ibrahimkaragul/arabnations-stop-this-man-who-is-dragging-you-to-war-against-turkey-2047585. 
genişçe yer verilmektedir. ${ }^{49}$ Binyamin Netanyahu'nun İsrail'le ilişkilerin normalleştirilmesi ile Arap ülkelerinin ABD'den F-35 tipi savaş uçağ alımı arasında bağ kuran açıklamaları da sıklıkla alıntılanmaktadır. ${ }^{50}$

Öte yandan Suudi Arabistan ve Misır yayın organlarında "Filistin halkının mağduriyetinin giderilmesi" ve kültürel farkl1lıklara saygı gösterilmesi" ana temaları inşa edilerek ahlaki değerlendirme yapılmaktadır. ${ }^{51}$ Bunlara ek olarak "egemenliğin ihlali" ve "içişlerine karışma" şeklinde iki tema daha öne çıkmaktadır. İsrail'le anlaşmanın hayata geçmesi durumunda, Filistin halkının uzun yıllardır yaşadığı mağduriyetin sonlanacağı ileri sürülmektedir. Bununla birlikte, Orta Doğu'da "farklı din ve kültürlerin birlikte yaşaması" adına atılan olumlu bir adım olarak değerlendirilmektedir. Arap ülkelerinin İsrail'le yakınlaşması, "farklı kültürlere saygı gösterilmesi gerektiği” ön plana çıkarılarak meşru gösterilmeye çalışılmaktadır. ${ }^{52}$ Bunun yanında her iki ülke medyası, Türkiye'nin 1949'da İsrail'i tanıyan ilk Müslüman ülke olmasına, bu tanımayı sürdürmesine ve onunla belli bir düzeyde ikili ilişkileri bulunmasına rağmen, Arap ülkelerinin İsrail'le normal ilişki kurmasına karşı tavır almasını "siyasi tutarsızlık"

49 "Netanyahu says Israel's annexation plan of occupied West Bank suspended 'for time being," Daily Sabah, 17 Ağustos 2020, https:/www.dailysabah.com/world/mid-east/ netanyahu-says-israels-annexation-plan-of-occupied-west-bank-suspended-for-timebeing; "EU calls Israel to abandon West Bank annexation plans," Yenisafak English, 15 Ağustos 2020, https://www.yenisafak.com/en/news/eu-calls-israel-to-abandon-westbank-annexation-plans-3536893.

50 "Trump Says UAE Bid to Buy F-35 Fighter Jets from US 'Under Review', "Fars News Agency, 20 Ağustos 2020, https://www.farsnews.ir/en/news/13990530000543/TrmpSays-UAE-Bid-By-F-35-Figher-Jes-frm-US; "How much is Palestine worth?," Daily Sabah, 18 Eylül 2020, https://www.dailysabah.com/opinion/columns/how-much-ispalestine-worth.

51 "UAE Says Peace Accord Is a Historic Step to Achieve Stability in Middle East," As Sharq Al Awsat, 17 Eylül 2020, https://english.aawsat.com/home/article/2512821/uaesays-peace-accord-historic-step-achieve-stability-middle-east; "UAE, Israel launch official phone links after normalisation deal," Daily News Egypt, 16 Ağustos 2020, https://dailynewsegypt.com/2020/08/16/uae-israel-launch-official-phone-links-afternormalisation-deal.

52 "Head of Israel's National Security Council visits UAE's Sheikh Zayed Grand Mosque," Al Arabiya, 1 Eylül 2020, https://english.alarabiya.net/en/News/gulf/2020/09/01/ Head-of-Israel-s-National-Security-Council-visits-UAE-s-Sheikh-Zayed-GrandMosque; "Sisi discusses Middle East peace process, Egyptian-American relations with head of World Jewish Congress," Al Arabiya, 17 Eylül 2020, http://english.ahram. org.eg/NewsContent/1/64/383320/Egypt/Politics-/Sisi-discusses-Middle-East-peaceprocess,-Egyptian.aspx. 
göstergesi olarak sunmaktadır. ${ }^{53}$ Bu bağlamda, Mısır medyası, Kahire'nin normalleşmeye yaklaşımını İsrail'i 1979'da tanıyan bir Arap ülkesi olması nedeniyle, diğer Arap ülkelerinin benzer bir davranış sergilemesini "siyasi tutarlıl1k" şeklinde nitelendirmektedir. ${ }^{54}$

Soruna ilişkin çözüm önerisi kategorisinin (Tablo IV) analizi yapıldığında aynı cepheleşme burada da fark edilmektedir. İran ve Türkiye medyası benzer temaları ön plana çıkararak çözüm önerisinde bulunmaktadır. İki ülke medyasında her şeyden önce "Filistin Davası'na ihanet anlamına gelen bu anlaşmadan geri adım atılmalı" ve "Filistin Meselesi yalnızca Arap devletlerinin değil, tüm İslam devletlerinin yer alacağ görüşmelerde çözüme kavuşturulmalı" şeklinde iki ana çözüm önerisi getirilmektedir. ${ }^{55}$ Bunların dışında alt çözüm önerisi de ileri sürülmektedir. Bu kapsamda, Trump yönetiminin bölgede anlaşmazlığın çözümüne dair "İsrail yanlısı" ve "dayatmacı" politikalarına karşı çıkılması gerektiği işlenmektedir. ${ }^{56}$ $\mathrm{Bu}$ süreçte Arap ve İslam ülkelerinin ortak hareket ederek söz konusu yakınlaşmaya karşı duruş sergilemesine ihtiyaç duyulduğu dile getirilmektedir. ${ }^{57}$ Özellikle bölgede yer alan İran, Türkiye ve Katar'ın, Filistin meselesinin bir oldubittiye getirilmesine karşı birlikte hareket

53 "Gargash: deal with Israel is not about Iran, dismisses Erdogan's criticism," Arab News, 16 Ağustos 2020, https://www.arabnews.com/node/1719786/middle-east; "Massive Qatari media campaign targets Arab opinion following UAE-Israel peace deal," $\mathrm{Al}$ Arabiya, 14 Ağustos 2020, https://english.alarabiya.net/en/features/2020/08/14/ Massive-Qatari-media-campaign-targets-Arab-opinion-following-UAE-Israelpeace-deal; "Implications of UAE-Israeli peace," Ahram Online, 18 Ağustos 2020, http://english.ahram.org.eg/NewsContent/4/0/378034/Opinion/0/Implications-ofUAEIsraeli-peace.aspx.

54 "Bahrain-Israel peace treaty welcomed regionally, internationally," Daily News Egypt, 12 Eylül 2020, https://dailynewsegypt.com/2020/09/12/bahrain-israel-peace-treatywelcomed-regionally-internationally/.

55 "Iran Urges Muslim Parliaments to Act Against UAE-Israel Deal," Kayhan, 18 Ağustos 2020, http://kayhan.ir/en/news/81905/iran-urges-muslim-parliaments-to-act-againstuaeisrael-deal; "Wake up call for Palestinian cause," Daily Sabah, 7 Eylül 2020, https:// www.dailysabah.com/politics/news-analysis/wake-up-call-for-palestinian-cause.

56 "Deal with the devil," Kayhan, 14 Ağustos 2020, http://kayhan.ir/en/news/81744/ deal-with-the-devil; "Experts: Normalization with Israel targets not just Palestinians but Turkey, Iran as well," Daily Sabah, 27 Eylül 2020, https:/www.dailysabah.com/ politics/news-analysis/experts-normalization-with-israel-targets-not-just-palestiniansbut-turkey-iran-as-well.

57 "Islamic Ummah's wrath will engulf UAE, Iranian parliamentary committee warns," Tehran Times, 24 Ağustos 2020, https://www.tehrantimes.com/news/451672/IslamicUmmah-s-wrath-will-engulf-UAE-Iranian-parliamentary. 
etmesinin önemi vurgulanmaktadır. ${ }^{58}$ İki ülke medyası bazı alt temalarda birbirinden ayrışmaktadır. Türkiye medyası, Filistin-İsrail anlaşmazlığının meşru çözüm zemini olan "iki devletli çözüme" geri dönülmesini gerekli görmektedir. Bu doğrultuda İsrail'in işgal etmiş olduğu Arap topraklarından çekilmeden ve başkenti Doğu Kudüs olan Filistin Devleti kurulmadan İsrail'le barış anlaşması imzalanmaması gerektiğinin altı çizilmektedir. ${ }^{59}$ İran medyası İsrail'in bölgede "var olma hakkına" gönderme yapan bu tür çözüm önerilerini benimsememektedir. Bunun yanında Türkiye medyas1, İsrail' in saldırgan davranışlarını meşrulaştıran adımlardan kaçınılması gerektiğine, buna karşın İran medyası ise İsrail'in bölgedeki varlığını meşrulaştıran adımlardan uzak durulmasına dikkat çekmektedir. ${ }^{60}$

Diğer yandan Suudi Arabistan ve Mısır medyası, her şeyden önce İsrailFilistin anlaşmazlığının çözümü hakkında Arap ülkeleri ve halklarının Suudi Arabistan, Misır ve BAE liderliğinin stratejik aklına güvenmesi gerektiği önerisini geliştirmektedir. ${ }^{61}$ Bunun yanında İsrail-Filistin

58 "Iran, Turkey, and Qatar can form alliance: Hamas representative in Tehran," Tehran Times, 7 Eylül 2020, https://www.tehrantimes.com/news/452187/Iran-Turkey-andQatar-can-form-alliance-Hamas-representative; "Is UAE's alliance with Israel against Iran or Turkey?," Daily Sabah, 20 Ağustos 2020, https://www.dailysabah.com/opinion/ columns/is-uaes-alliance-with-israel-against-iran-or-turkey.

59 "UAE-Israel deal breaks Arab unity, endangers Palestinian cause, experts say," Daily Sabah, 11 Eylül 2020, https:/www.dailysabah.com/politics/news-analysis/uae-israeldeal-breaks-arab-unity-endangers-palestinian-cause-experts-say; "Palestine says UAE's deal with Israel 'betrays' Jerusalem," Yenisafak English, 14 Ağustos 2020, https://www.yenisafak.com/en/world/palestine-says-uaes-deal-with-israel-betraysjerusalem-3536786.

60 "Rouhani warns UAE: Lest deal with Tel Aviv open a way for Israeli presence in the region," Tehran Times, 15 Ağustos 2020, https://www.tehrantimes.com/ news/451275/Rouhani-warns-UAE-Lest-deal-with-Tel-Aviv-open-a-way-for-Israeli; "Regional disputes escalate after controversial Israel-UAE deal," Daily Sabah, 17 Ağustos 2020, https://www.dailysabah.com/world/mid-east/regional-disputesescalate-after-controversial-israel-uae-deal; "Deal to Spell 'Dangerous Future' for UAE Rulers," Kayhan, 15 Ağustos 2020, http://kayhan.ir/en/news/81775/deal-to-spell$\% \mathrm{E} 2 \% 80 \% 98$ dangerous-future $\% \mathrm{E} 2 \% 80 \% 99$-for-uae-rulers.

61 "UAE-Israel relationship is a sovereign decision, not directed against anyone: Gargash," Al Arabiya, 9 Eylül 2020, https://english.alarabiya.net/en/News/gulf/2020/09/09/UAEIsrael-relationship-is-a-sovereign-decision-not-directed-against-anyone-Gargash. "UAE-Israel deal will not come at expense of Palestinian cause: Abu Dhabi Crown Prince," Al Arabiya, 31 Ağustos 2020, https://english.alarabiya.net/en/2020/09/01/ UAE-Israel-deal-will-not-come-at-expense-of-Palestinian-cause-Abu-Dhabi-CrownPrince. "UAE leads Gulf peace with Israel," Ahram Online, 20 Ağustos 2020, http:// english.ahram.org.eg/NewsContent/50/0/378004/AlAhram-Weekly/0/UAE-leadsGulf-peace-with-Israel.aspx. 
anlaşmazlığının Arap ülkelerinin "iç meselesi” olduğu, "dış müdahalenin" olmaması gerektiği ana önerilerden biri olarak sunulmaktadır. ${ }^{62}$ Burada "dış müdahale" ile kast edilen İran ve Türkiye'nin bölge meselelerine yönelik tutum ve davranışlarıdır. Nitekim bölgeye yönelik izledikleri politikalar nedeniyle güvenlik ve istikrarı bozduğu ileri sürülen İran ve Türkiye'nin önüne geçilmesi gerektiğine dair açıkça beyanatta bulunmaktan geri durulmamaktadır. ${ }^{63}$ Alt önerilere gelince, "çatışma ve savaş" ile anlaşmazlığın çözümüne dair yol alınamadığı, bundan böyle daha ziyade "diplomatik yolların" esas alınmasının gerekliliği üzerinde durulmaktadır. ${ }^{64}$ Bölge ülkelerinin barış ve güvenliğin teminine yönelik atılan adımları desteklemesinin önemine değinilmekte, diğer Arap ülkelerinin de İsrail'le benzer bir ilişki sürecini başlatmaları gerektiği belirtilmektedir. ${ }^{65}$ Tüm bu benzer söylemlerin yanında, 2002'de ilan edilen “Arap Barış İnisiyatifi'ne gönderme yapılarak İsrail'i tanıma konusunda ihtiyatlı davranma önerisini getiren Suudi medyası, bu konuda Mısır medyasından ayrışma

62 "Arab FMs Condemn Turkish, Iranian Interventions, Adhere to Peace Initiative," As sharq Al Awsat, 10 Eylül 2020, https://english.aawsat.com/home/article/2499676/arabfms-condemn-turkish-iranian-interventions $\%$ E2\%80\%A6-adhere-peace-initiative; "UAE, Israel launch official phone links after normalisation deal," Daily News Egypt, 16 Ağustos 2020, https://dailynewsegypt.com/2020/08/16/uae-israel-launch-officialphone-links-after-normalisation-deal/; "Egypt's FM says Jordan's quadripartite meeting targets framework to resolve Palestinian-Israeli conflict," Ahram Online, 24 Ağustos 2020, http://english.ahram.org.eg/NewsContent/1/64/383815/Egypt/Politics-/ Egypt $\%$ E2\%80\%99s-FM-says-Jordans-quadripartite-meeting-targ.aspx.

63 "Historic agreements boost Trump's image as a peacemaker," Arab News, 15 Eylül 2020, https://www.arabnews.com/node/1735051; "Is UAE's alliance with Israel against Iran or Turkey?," Daily Sabah, 20 Ağustos 2020, https://www.dailysabah.com/ opinion/columns/is-uaes-alliance-with-israel-against-iran-or-turkey.

64 "Halting annexation top UAE priority in Israel 'historic' deal: UAE official," Al Arabiya, 17 Ağustos 2020, https://english.alarabiya.net/en/News/gulf/2020/08/17/Haltingannexation-top-UAE-priority-in-Israel-historic-deal-UAE-official; "Iran, Turkey lash out at UAE over agreement with Israel," Egypt Independent, 14 Ağustos 2020, https:// egyptindependent.com/iran-turkey-lash-out-at-uae-over-agreement-with-israel/.

65 "The UAE-Israel deal gives Saudi Arabia a new opportunity," Al Arabiya, 16 Ağustos 2020, https://english.alarabiya.net/en/views/news/middle-east/2020/09/01/ The-UAE-Israel-deal-gives-Saudi-Arabia-a-new-opportunity-; "Arab-Israeli deals: A new Middle East?," Ahram Online, 17 Eylül 2020, http://english.ahram.org.eg/ NewsContent/50/1203/383184/AlAhram-Weekly/World/ArabIsraeli-deals-A-newMiddle-East.aspx; "UAE, Israel reach 'historic deal' to normalize relations," Arab News, 16 Ağustos 2020, https://www.arabnews.com/node/1718936/middle-east; "Road to Saudi ties with Israel being paved, cautiously," Egypt Independent, 22 Eylül 2020, https://egyptindependent.com/road-to-saudi-ties-with-israel-being-pavedcautiously/. 
göstermektedir. Suudi medyası Arap ülkelerinin İsrail'le diplomatik ilişki kurmasına karşı çıkmamakla birlikte, diplomatik müzakerelerin daha önce önerilen barış inisiyatifi çerçevesinde yürütülmesinin doğru olacağ kanaatini taşımaktadır. ${ }^{66}$

\subsection{Bölgesel Güç Rekabetinin Haber Çerçevelerine Yansıması}

Dış politika çizgisinin haber metinlerinin çerçevelenme biçiminin belirlenmesinde etkili olup olmadığının anlaşılması, ilk olarak, dört bölgesel gücün Orta Doğu'da izlediği dış politika çizgisinin bilinmesini gerektirmektedir. $\mathrm{Bu}$, haber metinlerinin, bulundukları ülkelerin Orta Doğu siyaseti doğrultusunda bir yayın politikası takip edip etmediklerinin anlaşılmasını sağlayacaktır. Böylece, medyanın siyaset kurumu içindeki "hâkim görüş" doğrultusunda hareket ederek kamuoyu nezdinde "rıza üretimi" faaliyeti üstlenip üstlenmediği açıklığa kavuşturulacaktır. İkinci olarak, meydana gelen gelişmelere yönelik yayın organlarında benimsenen haber çerçeveleri ile ilgili ülke yöneticilerinin benimsediği siyasi çerçeveler arasında uyumluluk bulunup bulunmadığına bakılmalıdır.

İlk olarak, bu dört bölgesel gücün dış politika çizgisinin anlaşılması, Orta Doğu'da yaşanan bölgesel güç rekabetinin bilinmesini gerektirmektedir. Son on yılda (2010-2020) Orta Doğu'da güç ilişkileri bakımından yapısal bir dönüşüm gerçekleşti. Bu yapısal değişim, her şeyden önce ABD'nin Orta Doğu'ya yönelik politikasını yeniden yapılandırmasıyla ilgilidir. $\mathrm{Bu}$ zaman diliminde ABD, Orta Doğu'da bölgesel güç ilişkilerinin dışında kalmaya çalışan ve geriden idare mantığı üzerine inşa edilen mevzilenme (retrenchment) stratejisini takip etti. İki safha üzerine inşa edilen mevzilenme stratejisi uyarınca süper güç (ABD), ilk önce bölgesel güç dengesinin muhafaza edilmesine yönelik dengeleme sorumluluğunu bölgesel güçlere paslamaktadır. Bölgesel güçler, yükselen diğer bölgesel gücü dengeleme sorumluluğunda başarılı olamadıkları takdirde, ikinci safha başlamakta ve süper güç dengeleme sorumluluğunu üstlenerek

66 "Foreign minister: Saudi Arabia is committed to Arab peace plan," Arab News, 19 Ağustos 2020, https://www.arabnews.com/node/1721706/saudi-arabia; "Saudi Arabia says it stands by Palestinians, supports efforts for just solution to issue: Cabinet," Ahram Online, 15 Eylül 2020, http://english.ahram.org.eg/NewsContent/2/8/381183/ World/Region/Saudi-Arabia-says-it-stands-by-Palestinians,-suppo.aspx. 
bölgeye doğrudan müdahale etmektedir. ${ }^{67} \mathrm{Bu}$ dönemde, bölgede yapısal değişikliğe yol açan ikinci gelişme ise Aralık 2010'da patlak veren Arap ayaklanmaları oldu. Tunus'ta başlayıp neredeyse bütün Arap ülkelerine yayılan Arap ayaklanmaları, Libya, Yemen ve Suriye'de iç savaşla sonuçlanırken, Bahreyn, Tunus, Mısır ve Irak'ta ise siyasal istikrarsızlığa yol açtı.

Geçen on yılda eşzamanlı olarak ortaya çıan ABD'nin bölge politikasını gözden geçirmesi ve Arap ayaklanmalarının yaşanması, Orta Doğu'da bölgesel güç boşluğu doğurdu. Ortaya çıkan bölgesel güç boşluğunda bölgesel güçler, bir taraftan firsatları kazanıma çevirmeye, diğer taraftan da beliren tehditlerin üstesinden gelmeye çalıştılar. Dolayısıyla Türkiye, İran, Suudi Arabistan ve Mısır'ın içinde bulunduğu yoğun bir bölgesel güç mücadelesi yaşanmaya başladı. Gitgide şiddetini artıran bölgesel rekabet, siyasi, ekonomik ve askeri yönleri bulunan çok boyutlu bir aşamaya ulaşt1. ${ }^{68}$ Yaşanan bölgesel rekabet ve çatışma medya üzerinden de yürütülmeye başlandi.

Bahse konu zaman diliminde bu devletler hem kendi aralarında hem de diğer bölge devletleriyle bölgesel ittifaklar tesis ettiler. ABD'nin mevzilenme stratejisinin ilk safhasını uyguladığı dönemde (2009-2016) Suudi Arabistan; Türkiye, Mısır ve Körfez ülkeleriyle ittifak ilişkisi kurarak İran'ın bölgesel yayılmacılığının önüne geçmeye yönelik büyük çaba harcadi ${ }^{69}$ Suudi Arabistan, mevzilenme stratejisinin ikinci safhasına geçildiği döneminde (2017-2020) ise, ABD'yle önceki dönemde bozulmuş olan ittifak ilişkisini yeniden kurarak İran'ın bölgesel yayılmacılı̆̆ının önüne geçmeye çalıştı. Bölge politikasını ABD'yle uyumlu ve koordineli bir çizgide yürütmeye başlayan Suudi Arabistan, İran'la daha gerilimli bir sürece girerken, Türkiye ile önceki dönemde kurmuş olduğu ittifak1 sonlandırdı. ${ }^{70}$ Bunun yanında diğer bölge ülkeleri Mısır, BAE ve Bahreyn

67 Marc Lynch, "Obama and the Middle East Rightsizing the U.S. Role," Foreign Affairs 94, no. 5 (2015): 18-26.

68 Richard N. Haass, “The Irony of American Strategy,” Foreign Affairs 92, no. 3 (2013): 57-67.

69 Gregory Gause, "The Future of U.S.-Saudi Relations," Foreign Affairs 95, no. 4 (2016): 114-126.

70 İsmail Akdoğan, Bağımlılık Bağımsızlık Arasında Suudi Arabistan (Ankara: Kadim Yayınları, 2020), 284. 
ile stratejik ortaklığını daha da derinleştirdi. Böylece Suudi Arabistan, Mısır, BAE ve Bahreyn'den müteşekkil bir “Arap Dörtlüsü” ortaya çıktı. ${ }^{71}$ ABD'yle yakın işbirliğinde bulunan ve İsrail'le yakınlaşma içerisine giren “Arap Dörtlüsü”, bölgede Türkiye ve İran karşıtllı̆ı üzerinden politika takip etmeye yöneldi. Aynı dönemde Türkiye ve İran'ın, bölgede izledikleri politikalara karşı çıkan ABD ve İsrail'le ilişkilerine gerilim ve çatışma hâkim olmaya başladı. "Arap Dörtlüsü’nün” İran ve Türkiye karşıtlığı, bölgede İsrail'le yakınlaşmalarını, bölge dışından da ABD'yle stratejik bir ittifak kurmalarını beraberinde getirdi.

Yaşanan bu bölgesel rekabet, söz konusu ülkelerin medya organlarının bölgesel gelişmeleri sunma biçimine de yansımakta, karşıtlık ve cepheleşme iklimi medya metinlerinde de açıkça fark edilmektedir. Dolayısıyla Arap ülkelerinin İsrail'le normalleşme girişiminin medyada çerçevelenme biçiminin, bu dört bölgesel gücün bu gelişmeye yönelik tutum ve davranışlarıyla yakından ilgili olduğu düşünülmektedir. Her bir medya organının haber çerçeveleme tarzının, ait olduğu ülkenin siyasi elitlerinin ortaya koyduğu siyasi çerçeveleri haber metinlerine yansıttıkları gözlemlendi. Haber çerçeveleri, siyasi çerçevelerde kullanılan anahtar kelimeler ve kavramları sıklıkla kullanarak ait oldukları ülkelerin söz konusu yakınlaşmaya ilişkin tavrıyla paralel hareket etmektedir.

Siyasi çerçeveler, incelenen dört ülkenin devlet başkanları ve dışişleri bakanlarının söz konusu normalleşme anlaşmasına dair beyanatlarına bakılarak ortaya çıkarıldı. Siyasi çerçevelere bakıldığında Türkiye ile İran'daki siyasi yetkililerin Arap ülkeleri ile İsrail arasında yaşanan normalleşme girişimine olumsuz yaklaşıp karşı çıktıkları, buna karşın Suudi Arabistan ile Misır liderliğinin ise olumlu yaklaşıp desteklediği anlaşılmaktadır. $\mathrm{Bu}$ bakımdan, haber çerçevelerinde gözlemlenen cepheleşme, aslında söz konusu ülkelerin dış politika tavırlarında izlenen cepheleşmenin bir uzantısı olarak ortaya çıkmaktadır. Türkiye ve İran siyasi liderliğinin açıklamalarına bakıldığında, "tarihi hata", "bölgesel güvenlik ve istikrarın tehlikeye girdiği", "Filistin ve İslam davasına ihanet edildiği", "bölge halkının menfaatlerinin karşılanmadı̆̆ı", "Filistin halkının

"Joint Statement by Saudi Arabia, UAE, Bahrain and Egypt Relating to New Terror Designation," The Ambassy of the Kingdom of Saudi Arabia, 25 Temmuz 2017, https:// www.saudiembassy.net/statements/joint-statement-saudi-arabia-uae-bahrain-andegypt-relating-new-terror-designations. 
iradesinin yok sayıldığı", "BAE, İsrail ve ABD'nin çıkarlarını yansıttığı", "İsrail'e taviz verildiği" ve "İsrail'in ödüllendirildiği" şeklinde kelime, kavram ve ifadeler öne çıkmaktadır. ${ }^{72} \mathrm{Bu}$ anlamda siyasi çerçeveler, haber çerçeveleriyle ciddi bir benzerlik göstermektedir. Bununla birlikte, Türkiye "iki devletli çözümün iflası" ve "Arap barış inisiyatifinin ihlali" şeklinde ifadelere yer vererek ayrışırken, ${ }^{73}$ İran ise "Siyonist rejimle müzakere edildiği", "işgalci Siyonist rejimin bölgedeki varlığının tanındığı" ve "direniş ekseninin hedef alındı̆̆ı" şeklindeki ifadelerle ayrışmaktadır. ${ }^{74}$ Dolayısıyla Türkiye ile İran arasında yukarıda haber çerçevelerinde ortaya çıkan nüans fark1, siyasi çerçevelerde de kendini göstermektedir. $\mathrm{Bu}$ ayrışma, İran'ın her ne şekilde olursa olsun İsrail'in bölgede varlı̆̆ını kabul etmeyen tavrı benimserken, Türkiye'nin Arap Barış İnisiyatifi uyarınca iki devletli çözümden yana tavır almasından kaynaklanmaktadır.

Suudi Arabistan ve Mısır'da siyasi yetkililerin açıklamalarına bakıldı̆̆ında, İsrail'le normalleşme anlaşmasına yönelik benzer bir tutumun benimsendiğ ve olumlu yaklaşıldığı görülmektedir. İki ülke siyasi yetkililerinin gelişmeye dair açıklamaları incelendiğinde, "tarihi bir adım", "bölgesel güvenlik ve istikrarın temin edileceği”, "bölgesel barışın sağlanacă̆ı",

72 "Rouhani Urges Betrayers of Palestine Not to Claim Arabism," Fars News Agency, 16 Eylül 2020, https://www.farsnews.ir/en/news/13990626000994/Rhani-UrgesBerayers-f-Palesine-N-Claim-Arabism; " 'Israel-UAE deal null and void for Turkey,"” Yenisafak English, 15 Ağustos 2020, https://www.yenisafak.com/en/news/israel-uaedeal-null-and-void-for-turkey-3536894; "Wake up call for Palestinian cause," Daily Sabah, 7 Eylül 2020, https://www.dailysabah.com/politics/news-analysis/wake-upcall-for-palestinian-cause; "Turkey mulls withdrawing envoy, suspending ties with Abu Dhabi over deal with Israel," Hurriyet Daily News, 14 Ağustos 2020, https:// www.hurriyetdailynews.com/turkey-mulls-withdrawing-envoy-suspending-tieswith-abu-dhabi-over-deal-with-israel-157389; "Iran, Turkey, and Qatar can form alliance: Hamas representative in Tehran," Tehran Times, 7 Eylül 2020. https://www. tehrantimes.com/news/452187/Iran-Turkey-and-Qatar-can-form-alliance-Hamasrepresentative.

73 "Ruling AKP denounces UAE-Israel deal," Hurriyet Daily News, 15 Ağustos 2020, https://www.hurriyetdailynews.com/ruling-akp-denounces-uae-israel-deal-157423; “Turkey criticizes Bahraini deal with Israel," Hurriyet Daily News, 12 Eylül 2020, https://www.hurriyetdailynews.com/turkey-criticizes-bahraini-deal-with-israel-158198.

74 "Rouhani warns UAE: Lest deal with Tel Aviv open a way for Israeli presence in the region," Tehran Times, 15 Ağustos 2020, https://www.tehrantimes.com/news/451275/ Rouhani-warns-UAE-Lest-deal-with-Tel-Aviv-open-a-way-for-Israeli; "Iran, Turkey, and Qatar can form alliance: Hamas representative in Tehran," Tehran Times, 7 Eylül 2020, https://www.tehrantimes.com/news/452187/Iran-Turkey-and-Qatar-can-formalliance-Hamas-representative. 
adil, kapsamlı ve kalıcı barışın elde edileceği”, "anlaşmazlığın diplomatik/ barışç1 yollarla çözümü” ve "İsrail ilhakının önleneceği” şeklinde ifadeler ön plana çıkmaktadır. ${ }^{75}$ Burada da siyasi çerçevelerde kullanılan, kelime, kavram ve ifadeler haber çerçevelerinde kullanılanlarla büyük bir benzerlik içerisindedir. Bununla birlikte Suudi Arabistan liderliğinin ifadelerinde anlaşmaya olumlu yaklaşılmakla birlikte, ihtiyatlı bir dil kullanıldığ fark edilmektedir. Suudi liderliği "Arap Barış İnisiyatifi” çerçevesinde iki devletli çözümden yana olunduğunun altını çizmektedir. ${ }^{76}$ Mısır, Suudi Arabistan'dan farklı olarak "bölgesel kalkınma ve refahın sağlanacağına" vurgu yapmaktadır. ${ }^{77}$ Sonuç olarak, bölgesel güçlerin Orta Doğu' ya yönelik dış politika çizgisi ile bu ülkelerin yazılı basınının anlaşmayı çerçeveleme biçimi arasında nedensel bir ilişkinin olduğu anlaşılmaktadır.

\section{Sonuç}

$\mathrm{Bu}$ çalışma, Arap-İsrail normalleşmesinin Orta Doğu'daki bölgesel güçlerin haber medyasında hangi çerçevelerle sunulduğunu, ortaya çıkan benzerlik ve farklılıkların nereden kaynaklandığını inceledi. Medya-dış politika ilişkisi konusunda ileri sürülen yaklaşımlar ve haber çerçeveleme kavramı doğrultusunda yürütülen araştırma sonucunda şu temel bulgulara ulaşıldı: İlk olarak, incelenen haber kuruluşlarının İbrahim Anlaşması'nın

75 "UAE has long-lasting support for Palestine: Abu Dhabi Palestinian Business Council," Al Arabiya, 18 Ağustos 2020, https://english.alarabiya.net/News/gulf/2020/08/18/ UAE-has-long-lasting-support-for-Palestine-Abu-Dhabi-Palestinian-BusinessCouncil; "UAE summons Iranian Chargé d'Affairs over Rouhani's Israel deal threats," Arab News, 16 Ağustos 2020, https://www.arabnews.com/node/1720326/middle-east; "UAE-Israel deal step to Middle East peace: Egypt's El-Sisi," Arab News, 2 Eylül 2020, https://www.arabnews.com/node/1728466/middle-east; "Bahrain-Israel peace treaty welcomed regionally, internationally," Daily News Egypt, 12 Eylül 2020 https:// dailynewsegypt.com/2020/09/12/bahrain-israel-peace-treaty-welcomed-regionallyinternationally/; "UAE leads Gulf peace with Israel," Ahram Online, 10 Ağustos 2020, http://english.ahram.org.eg/NewsContent/50/0/378004/AlAhram-Weekly/0/UAEleads-Gulf-peace-with-Israel.aspx.

76 "Foreign minister: Saudi Arabia is committed to Arab peace plan," Arab News, 19 Ağustos 2020, https://www.arabnews.com/node/1721706/saudi-arabia.

77 "The art of the deal," Ahram Online, 20 Ağustos 2020, http://english.ahram.org.eg/ NewsContent/50/1203/378049/AlAhram-Weekly/World/The-art-of-the-deal.aspx; "Bahrain-Israel peace treaty welcomed regionally, internationally," Daily News Egypt,12 Eylül 2020, https://dailynewsegypt.com/2020/09/12/bahrain-israel-peacetreaty-welcomed-regionally-internationally/. 
belirli yönlerini bilinçli bir şekilde seçerek ön plana çıkardığ 1 ve diğer yönlerini ise görmezden gelerek geri plana attı̆̆1 gözlemlendi. Haber kuruluşlarının meydana gelen sosyal gerçekliği belirli bir hâkim görüş doğrultusunda yeniden inşa ettiği, bu sayede kamuoyunun Arap-İsrail normalleşmesi hakkındaki algısını yönlendirmeye çalıştı̆̆ı ortaya çıktı. Tüm bu süreçte basın organlarının, İbrahim Anlaşması'nı belirli anahtar kelimeler, basmakalıp ifadeler ve alıntılar kullanarak belirli bir çerçeve içinde okuyucusuna sunmakta olduğu görüldü. Çerçeveleme kavramının ileri sürdüğü argümanlar göz önünde bulundurulduğunda, medyanın esas itibariyle kamuoyuna basit bir bilgi aktarımında bulunmaktan ziyade, belirli bir amaç doğrultusunda haber üretiminde bulunarak toplumun algısını biçimlendirmeye çaba harcadığı anlaşılmaktadır.

İkinci olarak, dört bölgesel gücün haber kuruluşlarında benzerlik ve farklılıklar tespit edildi. Arap-İsrail yakınlaşmasına ilişkin haber çerçeveleri incelendiğinde haber diline iki karşıt görüşün hakim olduğu gözlemlendi. Türkiye ve İran medyası, Arap-İsrail normalleşmesini olumsuz çerçevelerle okuyucu kitlesine sunarken, buna karşılık Suudi ve Mısır medyası olumlu çerçevelerle sunmaktadır. Üçüncü olarak, incelenen basın kuruluşlarının haber çerçeveleri ile ait oldukları ülkelerin siyasi çerçeveleri arasında uyumluluk saptandı. Bölgesel güçlerin Orta Doğu'da takip ettikleri diş politika çizgileri ile incelenen ülkelerin yayın organlarının haber sunum biçimleri/yayın politikaları arasında nedensel ilişki bulunmaktadır. Dört ülkede bulunan siyasal iktidarın İbrahim Anlaşması'na yönelik siyasi yaklaşımının, aynı ülkelerdeki haber kuruluşları tarafından benimsendiği görüldü. Orta Doğu'da son on yılda (2010-2020) bölgesel güçler arasında yaşanan güç rekabetinin haber kuruluşlarının gerçekliği yansıtma pratiğine yansıdığı kanaatine ulaşıldı. Sonuç olarak çalışma sürecinde medyadış politika ilişkisi konusunda literatürde yer alan üç temel yaklaşımdan "medyanın siyaset kurumunun etkisi altında haber üretimimde bulunduğu" şeklindeki argümanın geçerliliğine yönelik bulgulara ulaşıldı. Medya, siyaset kurumunun dışa dönük tutum ve davranışlarını kamuoyu nezdinde meşrulaştıran ve nihayetinde toplumda "rıza üretimi"nde bulunan işlevsel bir araç şeklinde pratik sergilemektedir. 


\section{Kaynakça}

Akdoğan, İsmail. Bağımlılık Bağımsızlık Arasında Suudi Arabistan. Ankara: Kadim Yayınları, 2020.

Bateson, Gregory. Steps to an Ecology of Mind. New York: Ballantine Books, 1972.

Bennet, Lance. "Toward a Theory of Press-State Relations in the United States." Journal of Communication 40, no. 2 (1990): 103-125.

Berry, Nicholas. Foreign Policy and the Press: An Analysis of New York Times ' Coverage of U.S. Foreign Policy. New York: Greenwood Press, 1990.

Cohen, Bernard C. The Press and Foreign Policy. New Jersey: Princeton University Press, 1965.

Culbert, David. “Television's Visual İmpact on Decision-Making in the USA.” Journal of Contemporary History 33, no. 2 (1998): 419-449.

Denk, Erdem. "Medya ve Uluslararası Politika." Uluslararası Ilişskiler 4, no. 13 (2007): 145-156.

Dijk, Teun Van. Racism and The Press. Londra: Routledge, 1991.

Entman, Robert M. "Framing U.S. Coverage of International News." Journal of Communication 41, no. 4 (1991): 6-27.

Entman, Robert M. "Framing: Towards Clarification of a Fractured Paradigm." Journal of Communication 43, no. 4 (1993): 51-58.

Entman, Robert M. Prejections of Power, Framing News, Public Opinion and U.S. Foreign Policy. Chicago: Universty of Chicago Press, 2004.

Gamson, William A. "News as Framing: Comments on Graber." American Behavioral Scientist 33, no. 2 (1989): 157-161.

Gause, Gregory. "The Future of U.S.-Saudi Relations." Foreign Affairs 95, no. 4 (2016): 114.126.

Gitlin, Todd. The Whole World is Watching. Berkeley: University of California Press, 1980.

Graber, Doris. Mass Media and American Politics. Washington: CQ Press, 1989. 
Haass, Richard N. "The Irony of American Strategy." Foreign Affairs 92, no. 3 (2013): 57-67.

Hallin, Daniel. The Unscored War: The Media and Vietnam. New York: Oxford University Press, 1986.

Herman, Edward S. "The Media's Role in U.S. Foreign Policy." Journal of International Affairs 47, no. 1 (1993): 23-45.

Herman, Edward S. ve Noam Chomsky. Manufacturing Consent: The Political Economy of Mass Media. New York: Pantheon Books, 1988.

Hoge, James. "Media Pervasiveness." Foreign Affairs 73, no. 4 (1994): 136-144.

Lippmann, Walter. Public Opinion. New York: The Free Press, 1997.

Livingston, Steven. Clarifying the CNN Effect: An Examination of Media Effect According to Type of Military Intervention. Joan Shorenstein Center on the Press, Politics and Public Policy, John Kennedy School of Government, Harvard University, 1997.

Lynch, Marc. "Obama and the Middle East Rightsizing the U.S. Role." Foreign Affairs 94, no. 5 (2015): 18-26.

O’Heffernan, Patrivk. Mass Media and American Foreign Policy. Norwood: Ablex Publishing, 1991.

Paletz, David L. ve Robert M. Entman. Media, Power and Politics. New York: Free Press, 1981.

Robinson, Piers. "The CNN Effect: Can the News Media Drive Foreign Policy." Review of International Studies 25, no. 2 (1999): 301-309.

Robinson, Piers. The CNN Effect: The Myth of News, Foreign Policy and Intervention. New York: Routledge, 2002.

Robinson, Piers. "Theorizing the Influence of Media on World Politics." European Journal of Communication 16, no. 4 (2001): 523-544.

Seib, Philip. Headline Diplomacy: How News Coverage Affects Foreign Policy. Londra: Greenwood Publishing, 1997.

Tuchman, Gaye. Making News: A Study in Construction of Reality. New York: The Free Press, 1978. 
Wolfsfeld, Gadi. The Media and Political Conflict. Cambridge: Cambridge University Press, 1997.

\section{İnternet Kaynakları}

"Arab FMs Condemn Turkish, Iranian Interventions... Adhere to Peace Initiative."Asharq Al Awsat. 10 Eylül 2020.

https:/english.aawsat.com/home/article/2499676/arab-fms-condemnturkish-iranian-interventions $\% \mathrm{E} 2 \% 80 \% \mathrm{~A} 6$-adhere-peace-initiative.

"Arab League slammed for not condemning UAE-Israel deal." Yenisafak English. 10 Eylül 2020. https://www.yenisafak.com/en/news/arableague-slammed-for-not-condemning-uae-israel-deal-3548940.

"Arab nations, stop the man who is dragging you to war against Turkey!." Yenisafak English. 11 Eylül 2020. https://www.yenisafak.com/en/columns/ibrahimkaragul/arab-nations-stop-this-man-who-is-draggingyou-to-war-against-turkey-2047585.

"Arab parties, groups decry Bahrain-Israel pact." Yenisafak English. 12 Eylül,2020. https://www.yenisafak.com/en/news/arab-parties-groupsdecry-bahrain-israel-pact-3549080.

“Arab-Israeli deals: A new Middle East?.” Ahram Online. 17 Eylül 2020. http://english.ahram.org.eg/NewsContent/50/1203/383184/AlAhramWeekly/World/ArabIsraeli-deals-A-new-Middle-East.aspx.

"Bahrain-Israel peace treaty welcomed regionally, internationally." Daily News Egypt. 12 Eylül 2020. https://dailynewsegypt.com/2020/09/12/ bahrain-israel-peace-treaty-welcomed-regionally-internationally/.

"Deal to Spell 'Dangerous Future' for UAE Rulers." Kayhan. 15 Ağustos 2020. http://kayhan.ir/en/news/81775/deal-to-spell-\%E2\%80\%98dang erous-future $\% \mathrm{E} 2 \% 80 \% 99$-for-uae-rulers.

"Deal With the Devil." Kayhan. 14 Ağustos 2020. http://kayhan.ir/en/ news/81744/deal-with-the-devil

"Deals of Shame." Fars News Agency. 17 Eylül 2020. https://www.farsnews.ir/en/news/13990627000810/Deals-f-Shame. 
"Did MBS give assurance to US of normalization with Israel?" Daily Sabah. 11 Eylül 2020. https://www.dailysabah.com/opinion/columns/ did-mbs-give-assurance-to-us-of-normalization-with-israel.

"Egypt's FM says Jordan's quadripartite meeting targets framework to resolve Palestinian-Israeli conflict." Ahram Online. 24 Ağustos 2020. http://english.ahram.org.eg/NewsContent/1/64/383815/Egypt/Politics-/Egypt $\%$ E2\%80\%99s-FM-says-Jordans-quadripartite-meetingtarg.aspx.

"Experts: Normalization with Israel targets not just Palestinians but Turkey, Iran as well." Daily Sabah. 27 Eylül 2020. https://www.dailysabah.com/politics/news-analysis/experts-normalization-with-israeltargets-not-just-palestinians-but-turkey-iran-as-well.

"First Israel-Emirates commercial flight set for Monday." Ahram Online. 28 Ağustos 2020. http://english.ahram.org.eg/NewsContent/2/8/378801/ World/Region/First-IsraelEmirates-commercial-flight-set-for-Mon. aspx.

"Foreign minister: Saudi Arabia is committed to Arab peace plan." Arab News. 19 Ağustos 2020. https://www.arabnews.com/node/1721706/ saudi-arabia.

"Gargash: deal with Israel is not about Iran, dismisses Erdogan's criticism." Arab News. 16 Ağustos 2020. https://www.arabnews.com/ node/1719786/middle-east.

"Halting annexation top UAE priority in Israel 'historic' deal: UAE official." Al Arabiya. 17 Ağustos 2020. https://english.alarabiya.net/ en/News/gulf/2020/08/17/Halting-annexation-top-UAE-priority-inIsrael-historic-deal-UAE-official.

"Hamas urges world leaders to break silence on Israel's Gaza blockade." Daily Sabah. 24 Ağustos 2020. https://www.dailysabah.com/world/ mid-east/hamas-urges-world-leaders-to-break-silence-on-israels-gazablockade.

"Head of Israel's National Security Council visits UAE's Sheikh Zayed Grand Mosque." Al Arabiya. 1 Eylül 2020. https://english.alarabiya. net/en/News/gulf/2020/09/01/Head-of-Israel-s-National-SecurityCouncil-visits-UAE-s-Sheikh-Zayed-Grand-Mosque. 
"Historic agreements boost Trump's image as a peacemaker." Arab News. 15 Eylül 2020. https://www.arabnews.com/node/1735051.

"How much is Palestine worth?” Daily Sabah. 18 Eylül 2020. https://www. dailysabah.com/opinion/columns/how-much-is-palestine-worth.

"Implications of UAE-Israeli peace." Ahram Online. 18 Ağustos 2020. http://english.ahram.org.eg/NewsContent/4/0/378034/Opinion/0/ Implications-of-UAEIsraeli-peace.aspx.

"In Israel, Kushner says 'stage is set' for Mideast progress." Daily News Egypt. 30 Ağustos 2020. https://egyptindependent.com/in-israelkushner-says-stage-is-set-f-mideast-progress/.

"Iran Urges Muslim Parliaments to Act Against UAE-Israel Deal." Kayhan. 18 Ağustos 2020. http://kayhan.ir/en/news/81905/iran-urgesmuslim-parliaments-to-act-against-uaeisrael-deal

"Iran, Turkey lash out at UAE over agreement with Israel." Daily News Egypt. 14 Ağustos 2020. https://egyptindependent.com/iran-turkeylash-out-at-uae-over-agreement-with-israel/.

"Iran, Turkey, and Qatar can form alliance: Hamas representative in Tehran." Tehran Times. 7 Eylül 2020. https://www.tehrantimes.com/ news/452187/Iran-Turkey-and-Qatar-can-form-alliance-Hamasrepresentative.

"Iranian Speaker's Aide: UAE to Be Engulfed in Zionist Regime's Fire." Fars News Agency. 14 Ağustos 2020. https://www.farsnews.ir/en/ news/13990524000505/Iranian-Speaker39-s-Aide-UAE-Be-Englfedin-Zinis-Regime39-s-Fire.

“Is UAE's alliance with Israel against Iran or Turkey?" Daily Sabah. 20 Ağustos 2020. https://www.dailysabah.com/opinion/columns/is-uaesalliance-with-israel-against-iran-or-turkey.

"Islamic Ummah's wrath will engulf UAE, Iranian parliamentary committee warns." Tehran Times. 24 Ağustos 2020. https://www.tehrantimes.com/news/451672/Islamic-Ummah-s-wrath-will-engulf-UAEIranian-parliamentary.

“"Israel-UAE deal null and void for Turkey'." Yenisafak English. 15 Ağustos 2020. https://www.yenisafak.com/en/news/israel-uae-deal-nulland-void-for-turkey-3536894. 
"Joint Statement by Saudi Arabia, UAE, Bahrain and Egypt Relating to New Terror Designation," The Ambassy of the Kingdom of Saudi Arabia, 25 Temmuz 2017, https:/www.saudiembassy.net/statements/jointstatement-saudi-arabia-uae-bahrain-and-egypt-relating-new-terrordesignations.

"Massive Qatari media campaign targets Arab opinion following UAEIsrael peace deal." Al Arabiya. 14 Ağustos 2020. https://english.alarabiya.net/en/features/2020/08/14/Massive-Qatari-media-campaign-targets-Arab-opinion-following-UAE-Israel-peace-deal.

"Mauritania affirms support for UAE following Israel deal to normalize relations." Al Arabiya. 16 Ağustos 2020. https://english.alarabiya. net/en/News/gulf/2020/08/16/Mauritania-affirms-support-for-UAEfollowing-Israel-deal-to-normalize-relations.

"Netanyahu Privately Accepts Arms Sales to UAE." Kayhan. 4 Eylül 2020. http://kayhan.ir/en/news/82433/netanyahu-privately-acceptsarms-sales-to-uae.

"Netanyahu says Israel's annexation plan of occupied West Bank suspended 'for time being'." Daily Sabah. 17 Ağustos 2020. https://www. dailysabah.com/world/mid-east/netanyahu-says-israels-annexationplan-of-occupied-west-bank-suspended-for-time-being.

"Oman Supports UAE Decision to Normalize Ties with Israel." Asharq Al Awsat. 14 Ağustos 2020. https://english.aawsat.com/home/article/2447746/oman-supports-uae-decision-normalize-ties-israel.

"Palestine says UAE's deal with Israel 'betrays' Jerusalem." Yenisafak English. 14 Ağustos 2020. https://www.yenisafak.com/en/world/ palestine-says-uaes-deal-with-israel-betrays-jerusalem-3536786.

"Peace deal at the White House." Ahram Online. 15 Eylül 2020. http:// english.ahram.org.eg/NewsContent/50/1203/381169/AlAhram-Weekly/World/Peace-deal-at-the-White-House.aspx.

"Pompeo to tour region after UAE-Israel deal." Ahram Online. 23 Ağustos 2020. http://english.ahram.org.eg/NewsContent/2/8/378381/World/ Region/Pompeo-to-tour-region-after-UAEIsrael-deal.aspx.

"Regional disputes escalate after controversial Israel-UAE deal." Daily Sabah. 17 Ağustos 2020. https://www.dailysabah.com/world/mid-east/ regional-disputes-escalate-after-controversial-israel-uae-deal. 
"Road to Saudi ties with Israel being paved, cautiously." Daily News Egypt. 22 Eylül 2020. https://egyptindependent.com/road-to-saudi-ties-withisrael-being-paved-cautiously/.

"Rouhani Urges Betrayers of Palestine Not to Claim Arabism." Fars News Agency. 16 Eylül 2020. https://www.farsnews.ir/en/ news/13990626000994/Rhani-Urges-Berayers-f-Palesine-N-ClaimArabism.

"Rouhani warns UAE: Lest deal with Tel Aviv open a way for Israeli presence in the region." Tehran Times. 15 Ağustos 2020. https://www. tehrantimes.com/news/451275/Rouhani-warns-UAE-Lest-deal-withTel-Aviv-open-a-way-for-Israeli.

"Ruling AKP denounces UAE-Israel deal." Hürriyet Daily News. 15 Ağustos 2020. https://www.hurriyetdailynews.com/ruling-akp-denouncesuae-israel-deal-157423.

"Saudi Arabia says it stands by Palestinians, supports efforts for just solution to issue: Cabinet." Ahram Online. 15 Eylül 2020 http:// english.ahram.org.eg/NewsContent/2/8/381183/World/Region/SaudiArabia-says-it-stands-by-Palestinians,-suppo.aspx.

“Saudi Arabia's Zionist Connection." Kayhan. 8 Eylül 2020. http://kayhan.ir/en/news/82594/saudi-arabia\%E2\%80\%99s-zionist-connection.

"Sisi discusses Middle East peace process, Egyptian-American relations with head of World Jewish Congress." Ahram Online. 17 Eylül 2020. http://english.ahram.org.eg/NewsContent/1/64/383320/Egypt/ Politics-/Sisi-discusses-Middle-East-peace-process,-Egyptian.aspx.

"The art of the deal." Ahram Online. 20 Ağustos 2020. http://english.ahram.org.eg/NewsContent/50/1203/378049/AlAhram-Weekly/World/ The-art-of-the-deal.aspx.

"The UAE-Israel agreement and the Arab World." Daily Sabah. 26 Ağustos, 2020. https://www.dailysabah.com/opinion/columns/the-uaeisrael-agreement-and-the-arab-world.

"The UAE-Israel deal gives Saudi Arabia a new opportunity." Al Arabiya. 16 Ağustos 2020. https://english.alarabiya.net/en/views/news/middle-east/2020/09/01/The-UAE-Israel-deal-gives-Saudi-Arabia-a-newopportunity-. 
"Trump Ready to Sell Any Weapons to 'Wealthy' Arabs." Kayhan. 15 Eylül 2020. http://kayhan.ir/en/news/82856/trump-ready-to-sell-anyweapons-to- $\%$ E2\%80\%98wealthy $\%$ E2\%80\%99-arabs.

"Trump Says UAE Bid to Buy F-35 Fighter Jets from US 'Under Review." Fars News Agency. 20 Ağustos 2020. https://www.farsnews.ir/ en/news/13990530000543/Trmp-Says-UAE-Bid-By-F-35-Figher-Jesfrm-US-'Under-Review'.

"Trump says UAE interested in buying F-35 jets, willing to pay 'a lot of money'." Yenisafak English. 20 Ağustos 2020.https://wa-piri-yenisafaken-mobil.azurewebsites.net/news/trump-says-uae-interested-inbuying-f-35-jets-willing-to-pay-a-lot-of-money-353723.4.

"Trump wants Jewish votes, UAE wants US arms, Israel wants Palestinian lands." Daily Sabah. 17 Ağustos 2020. https://www.dailysabah. com/opinion/columns/trump-wants-jewish-votes-uae-wants-us-armsisrael-wants-palestinian-lands.

“Trump-Netanyahu 'peace show'." Daily Sabah. 22 Eylül 2020. https:// www.dailysabah.com/opinion/op-ed/trump-netanyahu-peace-show.

"Turkey criticizes Bahraini deal with Israel." Hürriyet Daily News. 12 Eylül 2020. https://www.hurriyetdailynews.com/turkey-criticizesbahraini-deal-with-israel-158198.

"Turkey mulls withdrawing envoy, suspending ties with Abu Dhabi over deal with Israel." Hürriyet Daily News. 14 Ağustos 2020.https://www. hurriyetdailynews.com/turkey-mulls-withdrawing-envoy-suspendingties-with-abu-dhabi-over-deal-with-israel-157389.

"UAE 'will never abandon' Palestinians, Senior Official Says after Israel Deal." Al Arabiya. 17 Eylül 2020. https://english.alarabiya.net/en/ News/middle-east/2020/09/17/UAE-will-never-abandon-Palestinianssenior-official-says-after-Israel-deal.

"UAE and S. Arabia are part of the Zionist project in West Asia: Saudi analyst." Tehran Times. 16 Ağustos 2020. https://www.tehrantimes.com/news/451283/UAE-and-S-Arabia-are-part-of-the-Zionistproject-in-West-Asia.

"UAE has long-lasting support for Palestine: Abu Dhabi Palestinian Business Council." Al Arabiya. 18 Ağustos 2020. https://english.alarabi- 
ya.net/en/News/gulf/2020/08/18/UAE-has-long-lasting-support-forPalestine-Abu-Dhabi-Palestinian-Business-Council.

"UAE leads Gulf peace with Israel." Ahram Online. 20 Ağustos 2020. http://english.ahram.org.eg/NewsContent/50/0/378004/AlAhram-Weekly/0/UAE-leads-Gulf-peace-with-Israel.aspx.

"UAE position on Palestine in line with Arab consensus, says diplomat." Arab News. 15 Ağustos 2020. https://www.arabnews.com/ node/1719976/middle-east.

"UAE Says Peace Accord Is a Historic Step to Achieve Stability in Middle East." Asharq Al Awsat. 17 Eylül 2020. https://english.aawsat.com/ home/article/2512821/uae-says-peace-accord-historic-step-achievestability-middle-east.

"UAE summons Iranian Chargé d'Affairs over Rouhani's Israel deal threats." Arab News. 16 Ağustos 2020. https://www.arabnews.com/ node/1720326/middle-east.

"UAE, Israel deal against democracy in Arab world: Experts." Yenisafak English. 15 Ağustos 2020. https://www.yenisafak.com/en/news/uaeisrael-deal-against-democracy-in-arab-world-experts-3536895.

"UAE, Israel deal not surprising, but shameful." Yenisafak English. 15 Ağustos 2020. https://www.yenisafak.com/en/news/uae-israel-dealnot-surprising-but-shameful-3536897.

"UAE, Israel launch official phone links after normalisation deal." Daily News Egypt. 16 Ağustos 2020. https://dailynewsegypt. com/2020/08/16/uae-israel-launch-official-phone-links-afternormalisation-deal/.

"UAE, Israel reach 'historic deal' to normalize relations." Arab News. 16 A ğustos 2020. https://www.arabnews.com/node/1718936/middle-east.

"UAE, Israel strike deal to normalize ties, halt annexation plans." Daily News Egypt. 13 Ağustos 2020. https://dailynewsegypt. com/2020/08/13/uae-israel-strike-deal-to-normalize-ties-haltannexation-plans/.

"UAE-Israel agreement will threaten the national security of the region: Qatari analyst." Tehran Times. 23 Ağustos 2020. https://www.tehran- 
times.com/news/451587/UAE-Israel-agreement-will-threaten-thenational-security-of-th.

"UAE-Israel deal breaks Arab unity, endangers Palestinian cause, experts say." Daily Sabah. 11 Eylül 2020. https://www.dailysabah.com/politics/news-analysis/uae-israel-deal-breaks-arab-unity-endangers-palestinian-cause-experts-say.

"UAE-Israel deal step to Middle East peace: Egypt's El-Sisi." Arab News. 2 Eylül 2020. https://www.arabnews.com/node/1728466/middle-east.

"UAE-Israel deal will not come at expense of Palestinian cause: Abu Dhabi Crown Prince." Al Arabiya. 31 Ağustos 2020. https://english.alarabiya.net/en/2020/09/01/UAE-Israel-deal-will-not-come-at-expenseof-Palestinian-cause-Abu-Dhabi-Crown-Prince.

"UAE-Israel intelligence base on Yemeni island of Socotra." Daily Sabah. 5 Eylül 2020. https://www.dailysabah.com/opinion/op-ed/uae-israelintelligence-base-on-yemeni-islandof-socotra.

"UAE-Israel relationship is a sovereign decision, not directed against anyone: Gargash." Al Arabiya. 9 Eylül 2020. https://english.alarabiya. net/en/News/gulf/2020/09/09/UAE-Israel-relationship-is-a-sovereigndecision-not-directed-against-anyone-Gargash.

"UAE made strategic mistake by normalizing ties with Israel, says advisor." Tehran Times. 24 Ağustos 2020. https://www.tehrantimes.com/ news/451642/UAE-made-strategic-mistake-by-normalizing-ties-withIsrael-says.

"Wake up call for Palestinian cause." Daily Sabah. 7 Eylül 2020. https:// www.dailysabah.com/politics/news-analysis/wake-up-call-forpalestinian-cause.

"Zarif's assistant says UAE-Israel agreement not beneficial to the region." Tehran Times. 18 Ağustos 2020. https://www.tehrantimes.com/ news/451422/Zarif-s-assistant-says-UAE-Israel-agreement-notbeneficial-to. 